\title{
Spherulites and Aspiring Elites: The Identification, Distribution, and Consump- tion of Giali Obsidian (Dodecanese, Greece)
}

\author{
Tristan Carter $^{1}$, Daniel A. Contreras ${ }^{2}$, Kathryn Campeau ${ }^{3}$ and Kyle Freund ${ }^{4}$ \\ ${ }^{1}$ McMaster Archaeological XRF Lab / Department of Anthropology, CNH 524, McMaster University, 1280 \\ Main Street West, Hamilton, ON, L8S 4L9, Canada \\ E-mail: stringy@mcmaster.ca
}

${ }^{2}$ Institut Méditerranéen de Biodiversité et d'Ecologie marine et continentale (IMBE) / Groupement de recherche en économie quantitative d'Aix-Marseille (GREQAM), Aix-Marseille Université, Aix-en-Provence, France

E-mail: danielalexandercontreras@gmail.com

${ }^{3}$ McMaster Archaeological XRF Lab / Department of Anthropology, CNH 524, McMaster University, 1280 Main Street West, Hamilton, ON, L8S 4L9, Canada

E-mail: campekm@mcmaster.ca

${ }^{4}$ Department of Social Sciences, Indian River State College, 3209 Virginia Avenue, Ft. Pierce, FL 34981, USA E-mail: kfreund@irsc.edu

\begin{abstract}
This paper details the results of a survey of the obsidian sources on the island of Giali in the Dodecanese, Greece, together with a review of these raw materials' use from the Mesolithic to the Late Bronze Age (ninth to second millennium Cal BC). Elemental characterization of 76 geological samples from 11 sampling locations demonstrates the existence of two geochemically distinct sources, termed 'Giali A', and 'Giali B'. The latter material, available in small cobble form on the island's southwestern half, seems to have only been exploited by local residents during the Final Neolithic (fourth millennium Cal BC). In contrast, Giali A obsidian comprises a distinctive white-spotted raw material, available in large boulders on the northeastern half of Giali, whose use changed significantly over time. During the Mesolithic to later Neolithic it was mainly used for flake-based tool-production by local Dodecanesian populations. Further away, handfuls of Giali A obsidian are documented from Early Neolithic to Early Bronze Age sites in Crete, the Cyclades, and western Anatolia. The distribution of this material is likely indicative of population movement, and regional socio-economic interaction more generally, rather than a significant desire for, and trade of, the material itself. This changed in the Middle Bronze Age (second millennium Cal BC), when Giali A obsidian was reconceptualized as a valued raw material, and used by Cretan palace-based lapidaries to make prestige goods. This radical shift in traditions of consumption resulted from Cretan factions appropriating Anatolian and Egyptian elite value regimes and craft practices as a means of creating new means of social distinction within a larger Eastern Mediterranean political arena.
\end{abstract}

Keywords: Aegean prehistory, characterization, exchange, Giali, obsidian, value regimes 


\section{Introduction}

Insular lithic sources were significant toolmaking resources for prehistoric Mediterranean communities, particularly following the first colonization of these islands in the Neolithic (Cherry 1981; Farr 2006). The best-known of these are the obsidian sources on Sardinia in the west, on Lipari, Palmarola, and Pantellaria in the central Mediterranean, and Melos, Giali, and Antiparos in the Aegean. While the past 50 years have witnessed a wealth of literature discussing these sources' geology, geochemistry, and consumption histories, the research has focused on the Sardinian, Liparian, and Melian raw materials (Costa 2007; Carter 2009). Far less has been written on Antiparos obsidian until quite recently (Carter and Contreras 2012), and although the obsidians have been geochemically characterized the source area of Palmarola remains largely undocumented and little has been reported on the archaeology of Pantellaria. This paper provides the first study that integrates the characterization of Giali obsidian with documentation of the source area and diachronic analysis of its consumption.

Despite their comparable insular locations and relative accessibility, these sources have radically different histories of use. In the Aegean, obsidian was procured from Giali and Melos as early as the Late Pleistocene Upper Palaeolithic (at least the eleventh millennium $\mathrm{Cal}$ BC), and continued to be exploited until the twelfth century Cal BC (i.e., the very end of the Bronze Age-Carter 2009). In contrast, the central and western Mediterranean sources only began to be exploited during the Early Holocene Epi-Palaeolithic/Mesolithic (no earlier than the seventh millennium $\mathrm{Cal} \mathrm{BC}$ ); their use decreased significantly beginning in the Chalcolithic, and the material is virtually unknown from Bronze Age contexts (third millennium Cal BC) outside of Sardinia and Sicily (Freund 2014b: 242).

Situated in the Dodecanese islands of the Aegean, Giali is the source of a visually distinctive white-spotted obsidian (Figure 1). The spherulites that make the raw material so recognizable also hindered its ability to be flaked with any significant degree of control. It is thus unsurprising that this obsidian only enjoyed a limited use for tool-making, and was employed largely by local Dodecanesian communities to produce relatively ad hoc flake tools, from the Mesolithic through the Early Bronze Age (EBA—ninth to third millennium $\mathrm{Cal} \mathrm{BC}$ ). The limitations of the white-spotted obsidian are clearly evidenced by the fact that Final Neolithic (FN-fourth millennium Cal BC) populations living on Giali itself procured obsidian from Melos (230 km distant), to make their blades; the local raw material could not be worked in such a standardized manner (Sampson and Liritzis 1998: 104, fig. 13). Given these limitations, in the context of emergent metallurgy and with higher-quality lithic resources such as Melian obsidian accessible, one might have expected the exploitation of Giali obsidian to have diminished significantly with the onset of the Bronze Age. Beginning in the early Middle Bronze Age (MBA — second millennium Cal $\mathrm{BC})$, however, this 'poor-quality' white-spotted obsidian —and this Aegean obsidian alone - was procured by Cretan palace-based elites for the manufacture of an exclusive range of prestige goods, specifically vessels and sealstones.

The aim of this paper is to interpret how and why this obsidian came to be used, and apparently valued, in such radically different ways sometime after $2000 \mathrm{Cal}$ BC. Methodologically this involves what we refer to as an integrated characterization study'. This includes a survey of the Giali obsidian outcrops, elemental profiling of geological samples, and a review of the circulation of the island's white-spotted raw materials over time, focusing on how the material was consumed. The latter includes consideration of how Giali obsidian was worked, what was made from it, and the context of this consumption, by which we mean the value-regimes that underpinned crafting traditions, as much as the artifacts' provenience. This obsidian study is thus necessarily 


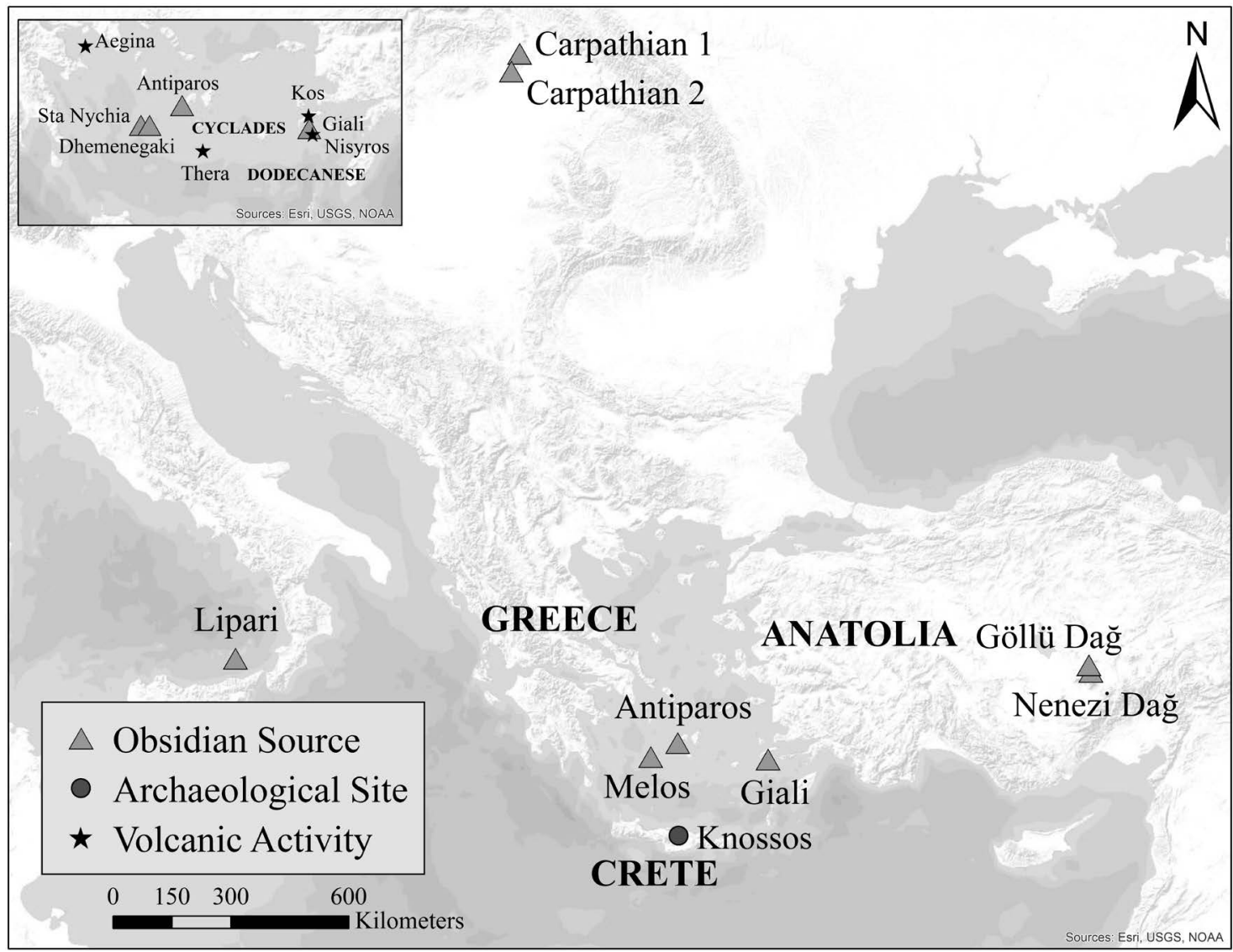

Figure 1. Major obsidian sources, sites, and other areas mentioned in the text.

situated within considerations of larger socioeconomic and ideological dynamics.

In focusing on Giali obsidian, this paper serves a dual purpose. First, it provides a long-overdue geo-archaeological characterization of the source itself. Second, it offers an explanation of why the western and central Mediterranean sources had such different histories of use to those in the Aegean. Finally, the study offers a compelling example of an often overlooked factor in obsidian sourcing studies: the potential influence of consumption practices on distribution patterns.

\section{Background}

The small island of Giali-'glass' in modern Greek-is one of the Aegean's three obsidian sources, along with Melos and Antiparos (Figure 1). While the prehistoric use of Giali obsidian has been discussed since the 1960s (Renfrew et al. 1965), there has been no detailed publication of the outcrops, and only limited chemical profiling of the raw materials. This paper provides the first detailed characterization of the source through a systematic survey of the obsidian flows and elemental characterization of 76 georeferenced geological samples, using energy dispersive $\mathrm{x}$-ray fluorescence (EDXRF) spectroscopy.

Giali is one of the Dodecanesian islands, located approximately $50 \mathrm{~km}$ southwest of the western Anatolian coast. This small island-ca. 6 sq $\mathrm{km}$-is oriented northeast to southwest, with raised hilly areas at either end linked by a narrow saddle (Figures 2 and 3). Today the only 
inhabitants belong to the mining concerns that exploit Giali's pumice, and the island is reached only by the company's private boat or by summer tourist vessels from Kos or Nisyros.

The Aegean is a tectonically active area, with a double volcanic arc running roughly northwest to southeast through the region (Figure 1); Giali forms part of the younger southern arc that also includes the islands of Aegina, Melos, Thera, and Nisyros (Shelford et al. 1982: 74-75). Both regions of volcanism have produced obsidian flows; the small obsidian source of Antiparos (Carter and Contreras 2012) comprises part of the older northern volcanic arc, while the obsidians from Melos and Giali are found in the geologically younger southern volcanic arc. The latter are significantly more recent: while volcanic deposits associated with Antiparos obsidian have been dated to 4.0 and 5.4 million years ago (Ma) (Innocenti et al. 1982: 90-91, table 1), the Melian sources of Sta Nychia (near the modern town of Adhamas) and Dhemenegaki have been fission-track dated to $1.57 \pm 0.12$ and $1.60 \pm 0.06 \mathrm{Ma}$ (Arias et al. 2006) respectively, and the ages of the Giali flows are reported as approximately 150,000 years ago (ka) (southwestern deposits) and 24-30 ka (northeastern deposits [Bigazzi and Radi 1981: 244, table 2]).

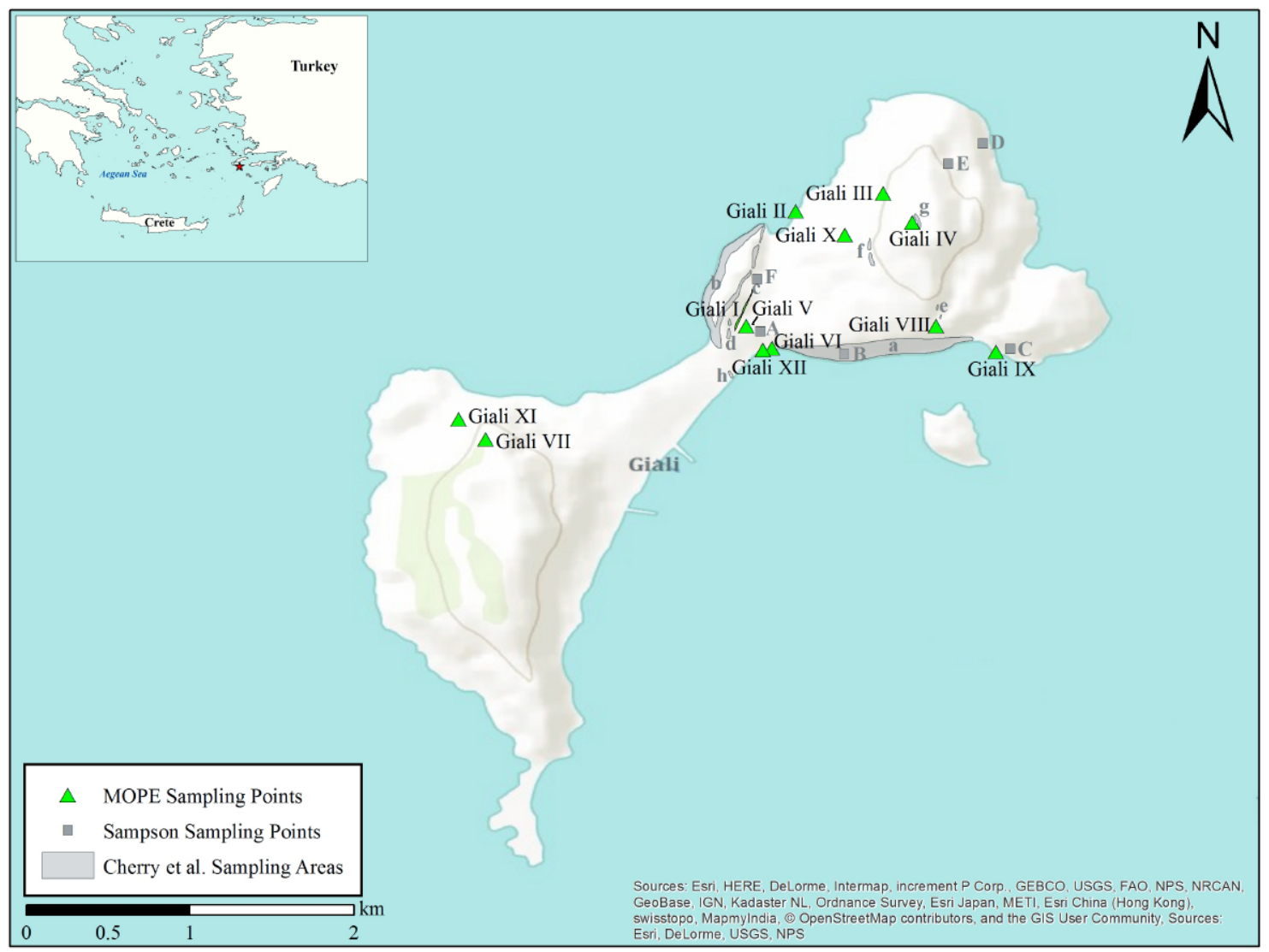

Figure 2. MOPE sampling locations (triangles), with areas described by Cherry et al. (n.d.) labeled in lowercase letters (a-h), and by Sampson (1988) and Katsarou et al. (2002) labeled in capital letters (A-F). Discrepancies in location may result from variable mapping precision and/or from the spatial extent of some exposures, which can be both extensive and heavily obscured by maquis. Labels may represent either precise locations sampled or entire outcrops, depending on the scale of the outcrop and how continuously it could be recorded. 


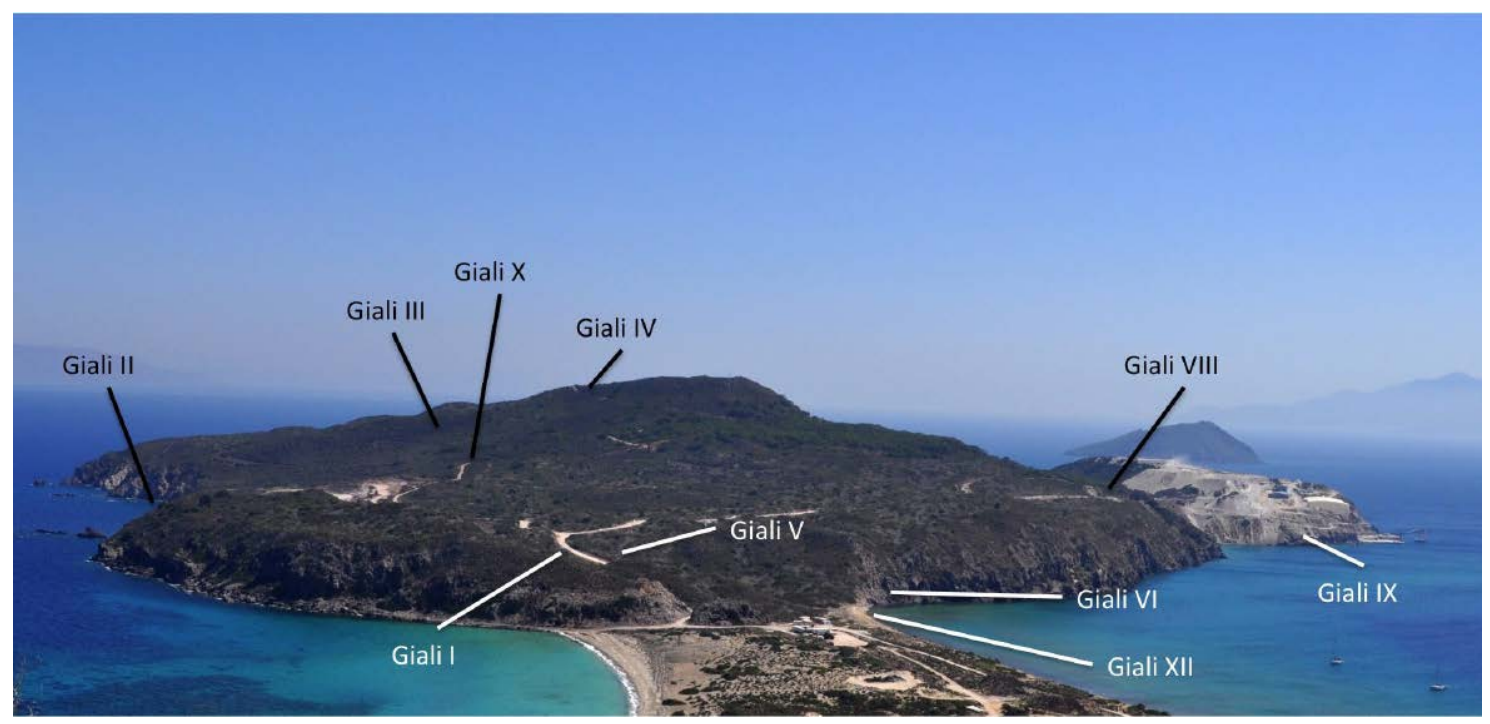

Figure 3. View of Giali from the southwest, showing sampling locations I-VI, VIII-X, and XII.

Thus while there have been recent claims for the use of Melian obsidian as early as the Lower Palaeolithic (Runnels 2014: 217), the Giali sources could not have been exploited until the Middle/ Upper Palaeolithic at the earliest.

While Giali was likely joined to the Anatolian continental landmass during most of the Pleistocene, recent sea-level reconstructions suggest that it has been an island since the Late Glacial Maximum, i.e. throughout the Holocene (Perissoratis and Conispoliatis 2003: 153, fig. 4; Lykousis 2009: 2042, fig. 5). As such, from the source's earliest exploitation in the Aegean Mesolithic (roughly the ninth and eighth millennia $\mathrm{Cal} \mathrm{BC}$ ), the procurement of obsidian would have necessarily involved seaborne travel.

\section{Past Research on Giali Obsidian}

As detailed below, most obsidian from Giali is in the form of a highly distinctive lustrous black glass liberally spotted with white spherulitic inclusions (Figure 4, top), a characteristic not associated with other Aegean obsidians. One of the first archaeological references to this material was made by Evans (1902-1903: 98) concerning a bowl made of a 'peculiar speckled variety of volcanic glass' from his excavations at Knossos (Figure 4, bottom), the renowned Bronze Age site of Crete, center of the 'Minoan' Civilization (Figure 1). Based on the opinion of an 'eminent mineralogist' and geologist, Evans (1901-1902: 12223) incorrectly believed the obsidian was from Lipari in the Aeolian islands. The vessel was thus proclaimed to constitute the earliest evidence of trade between Italy and Crete, which served to strengthen his theory that Crete subsequently acquired tin from Spain or Britain, a metals trade that had been forged via the 'old obsidian routes' (Evans 1921: 21, 87, 412). The fact that this 'liparite' obsidian was used to make a vessel of Egyptian form (Evans 1901-1902: 123, fig. 74), was also taken as evidence for connections between Crete and Early Dynastic Egypt. Evans, and his colleague Mackenzie (1904: 247), argued that such relations were important for the internal development of the Aegean'-i.e., that the rise of the Aegean's later Bronze Age palatial cultures was due to the influence of the Egyptian and Near Eastern 'primary' states. We return to the significance of this bowl and the theme of supra-regional political interaction below. 

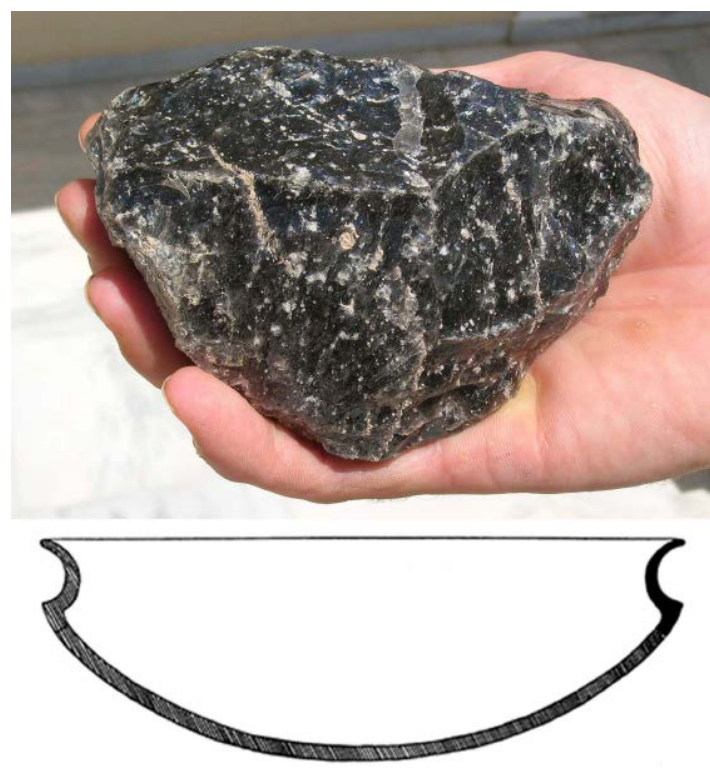

Figure 4. (top) Distinctive lustrous black and spherulitic Giali A obsidian from LM IB Mochlos, Crete (photography by M. Milić); (bottom) Bowl of Giali A obsidian from MM Knossos whose form imitates that of an Early Dynastic Egyptian stone vessel (from Evans 1901-1902: fig. 74, reproduced with permission of the British School at Athens), $15 \mathrm{~cm}$ diameter, preserved height $3.75 \mathrm{~cm}$.

The existence of obsidian on Giali was first reported in the 1920s, yet it was not until 1965 that Renfrew and colleagues demonstrated via a chemical characterization analysis that this was in fact the source of the white spotted material found on Crete, and not Lipari (Renfrew et al. 1965). While a seminal study for Aegean obsidian sourcing, the evidentiary basis for Giali obsidian's characterization was only three geological samples, and it lacked a detailed report of the source itself; these issues were then addressed in 1976 when Cherry and Torrence mapped and sampled the Giali outcrops (see Figure 2, above). While the project was never published, a manuscript-minus the elemental data-is available at the British School at Athens (Cherry et al. n.d.), and its results underpinned the publication by Buchholz and Althaus (1982) of a report on archaeology and mineralogy of Nisyros, Giali, and Kos.

Giali obsidian has been analyzed in a number of other characterization studies, though none included many samples, or geo-referenced materials (Pollard and Heron 2008: 75-87; also Stewart et al. 2003; Acquafredda and Paglionico 2004). While these studies mainly involved chemical profiling, a few studies focused on isotopic and mineral contents, geological age, and magnetic properties; the latter of these (McDougall et al. 1983) suggested the existence of a second obsidian source on the island, with reference to a magnetically distinct sample group from 'Giali beach' (McDougall et al. 1983: 447, fig. 3). We return to this material below (sample location Giali XII).

On Giali itself, a geo-archaeological survey in 1986 led to the excavation of an FN site, and discussions on the use of Giali obsidian by Dodecanesian Neolithic populations (Sampson 1984; 1988). The analytical component of this work led to claims for a second source on southwestern Giali; the associated geo-chemical data remains unpublished (Sampson and Liritzis 1998; Bassiakos et al. 2005).

\section{The Obsidian of Giali: Occurrence, Nature, and Sampling}

It was in this context that we initiated a new study of Aegean and Anatolian obsidian sources, the McMaster Obsidian Procurement Expedition [MOPE]. On Giali, our aim was to map and geo-chemically characterize accessible obsidian outcrops; geochemical analyses were carried out using energy dispersive $\mathrm{x}$-ray fluorescence spectroscopy (EDXRF) in the McMaster XRF Lab (MAX Lab). During two visits in 2010 and 2011 we surveyed the Giali obsidian outcrops, systematically sampling the raw materials to (a) investigate the availability and diversity of obsidian, and (b) establish an elemental database for artifact provenience studies. 
Pedestrian survey began in the middle of the island and proceeded northeastward following an outcrop of obsidian, perlite, and banded rhyolite that is exposed at the base of the slope along the western flank of the island. The major outcrops are located on this half of the island. Geological material was collected from 12 sample locations (detailed in Table 1 and Figures 2-3) to investigate potential geochemical variability between several distinct outcrops. The western slope of Giali's northern peak was also surveyed. Some of this work comprised formal survey, with $15 \mathrm{~m}$ spacing between fieldwalkers, but the steep and densely vegetated slopes soon rendered this impractical, and survey was often opportunistic. Obsidian is available in many locations on the northeastern half of Giali, but is uniformly so highly spherulitic that it fractures unpredictably and uncontrollably, making it a remarkably poor obsidian for knapping purposes (Figures 4 [top] and 5-10). Boulders and large outcrops are common, and probably as a result neither we nor

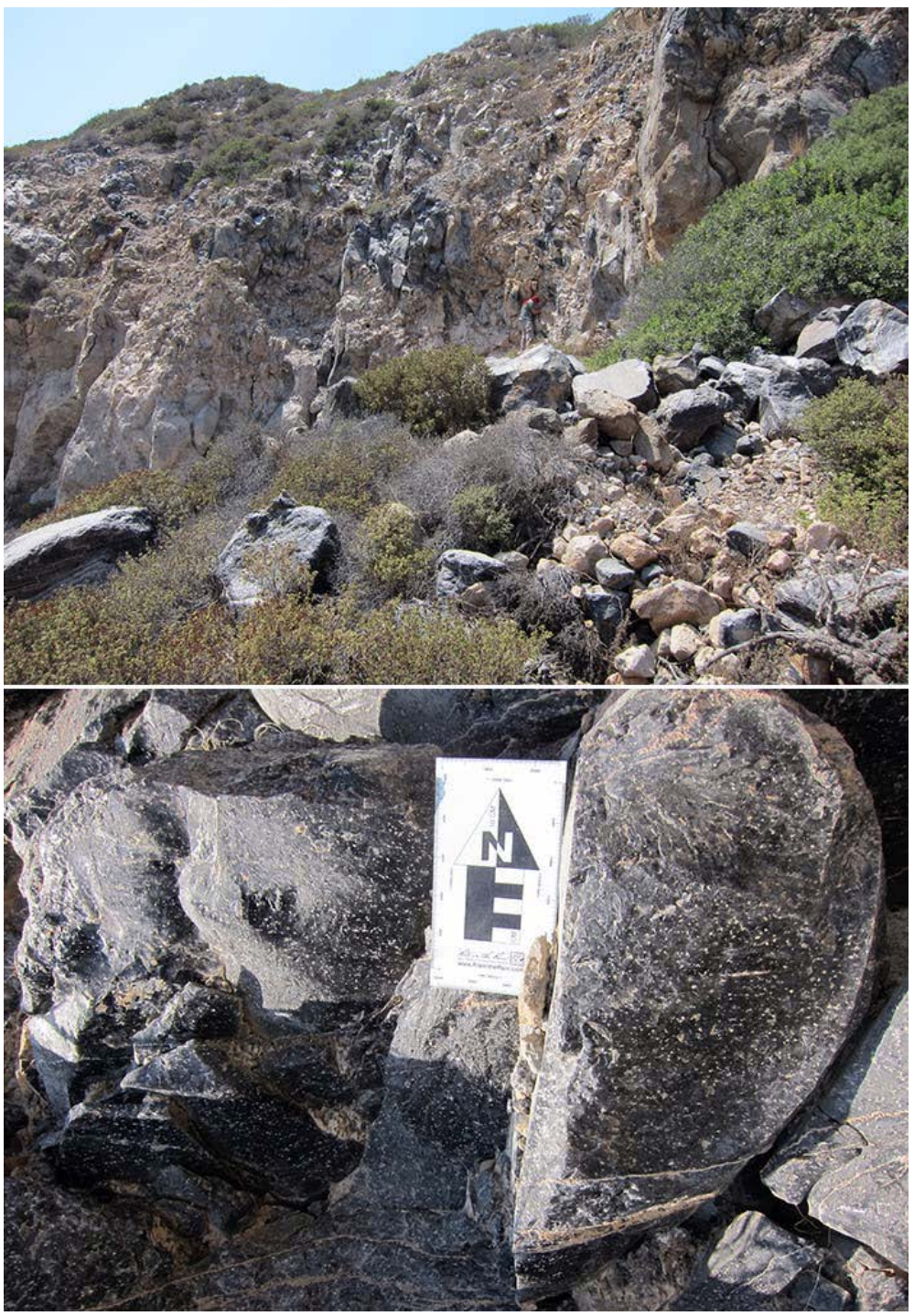

Figure 5. (top) Sampling location Giali I; (bottom) obsidian is abundant and readily available, but uniformly spherulitic. 


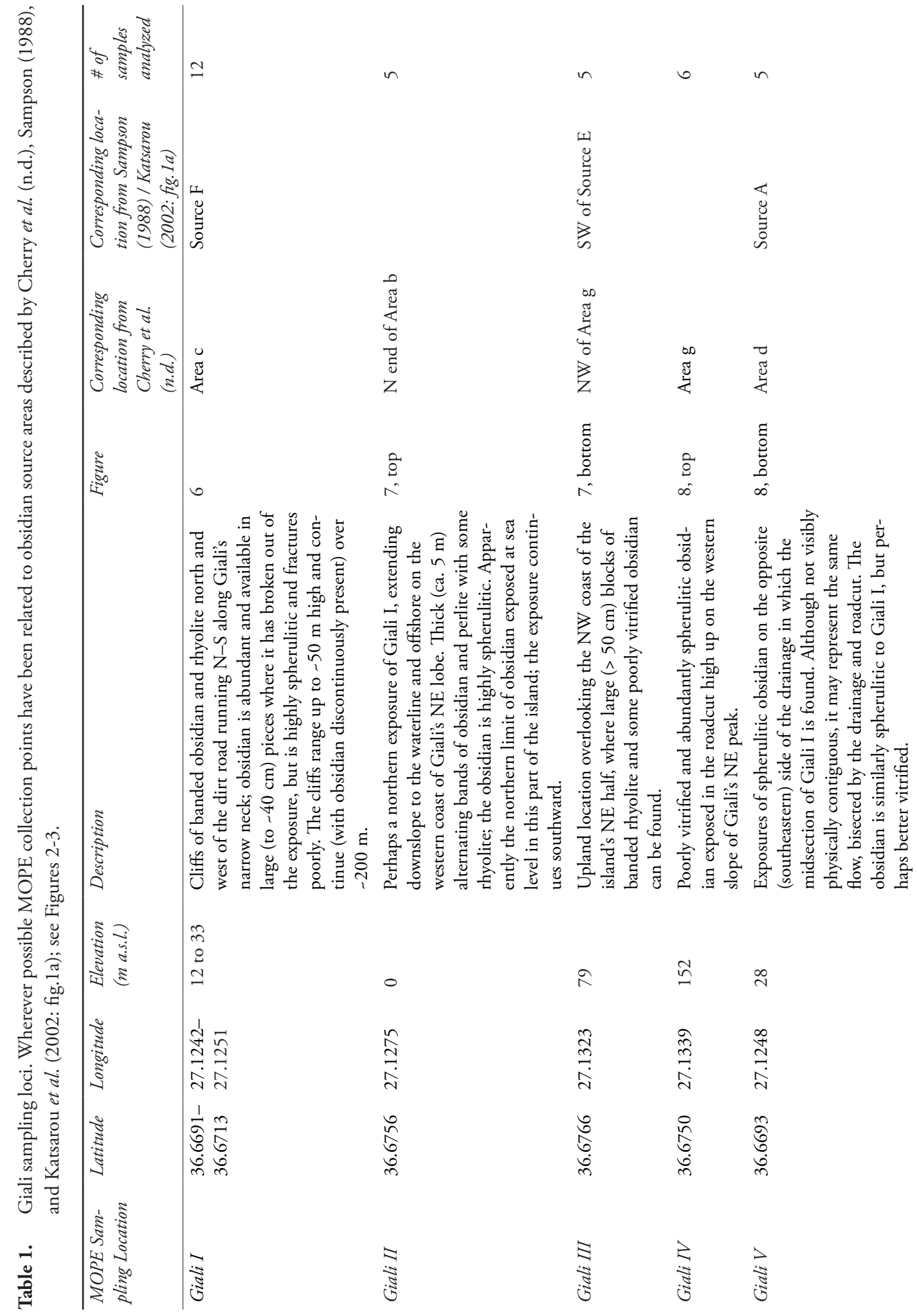




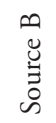

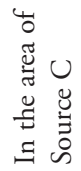

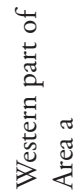

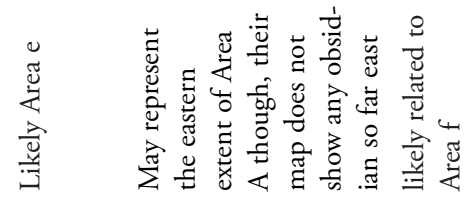

으

으

$=$
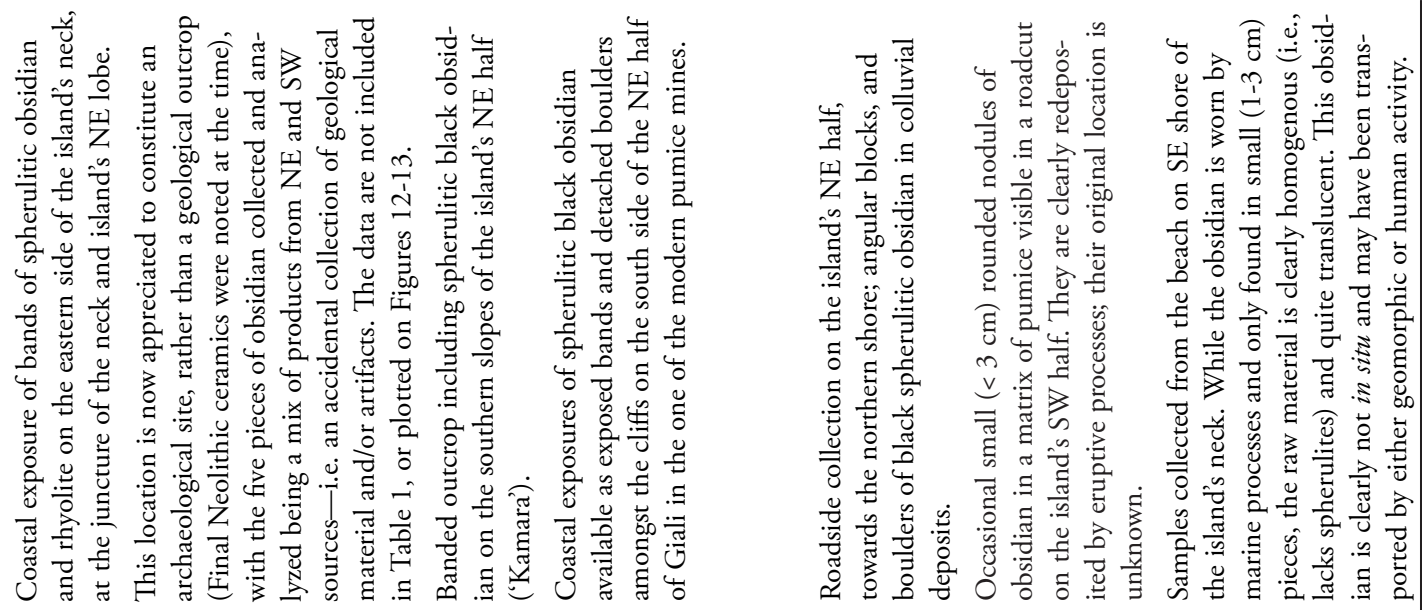

a

in $n$

은

○

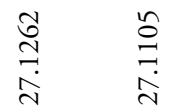

$\begin{array}{ll}n & n \\ n & n \\ & \text { ते }\end{array}$

$\begin{array}{ll}\text { กิ } & \text { ล } \\ \text { กิ } & \text { ป }\end{array}$

กิ

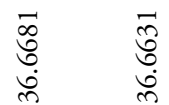

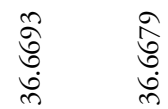

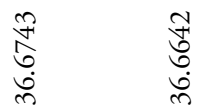

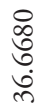

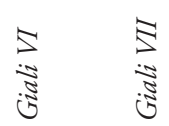

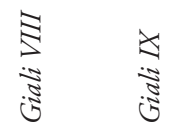

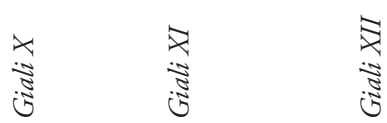




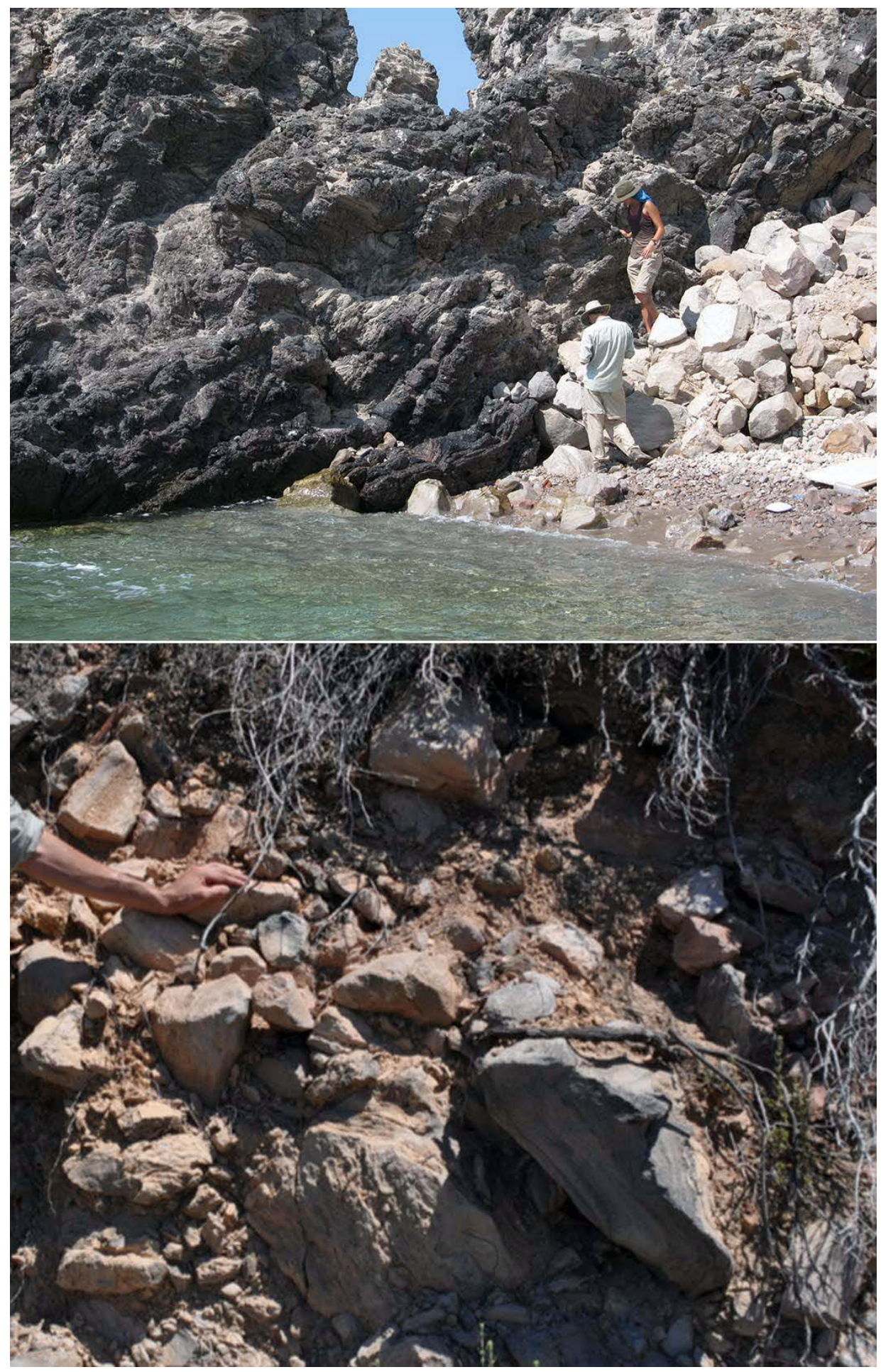

Figure 6. (top) Exposed flow of banded obsidian and perlite at the water's edge at sampling location Giali II; (bottom) obsidian included in colluvium exposed in roadcut at sampling location Giali III. 

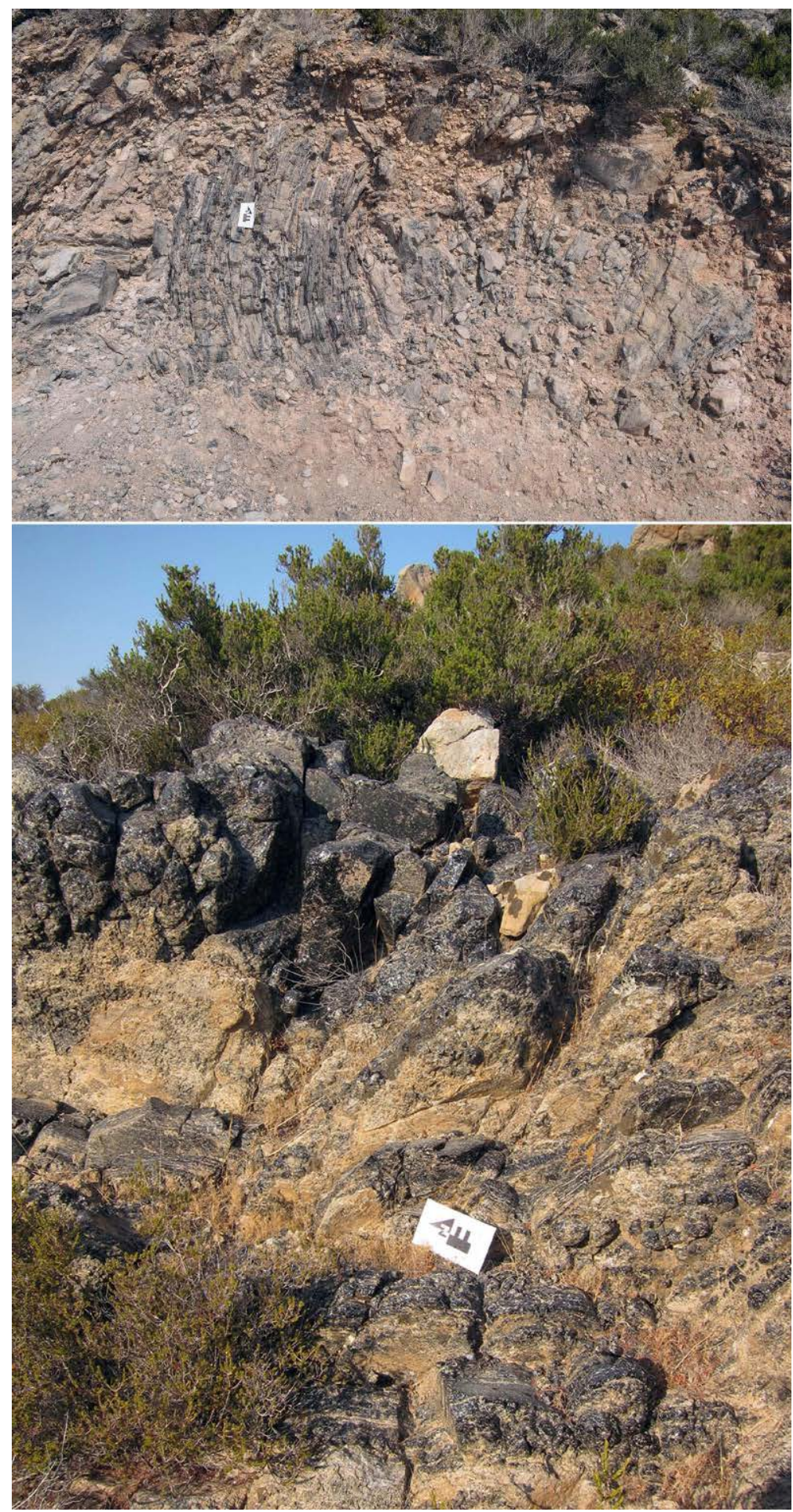

Figure 7. (top) Sampling location Giali IV, where obsidian is visible in a roadcut on Giali's northeastern peak; (bottom) flow of fairly well-vitrified but spherulitic obsidian at sampling location Giali V. 


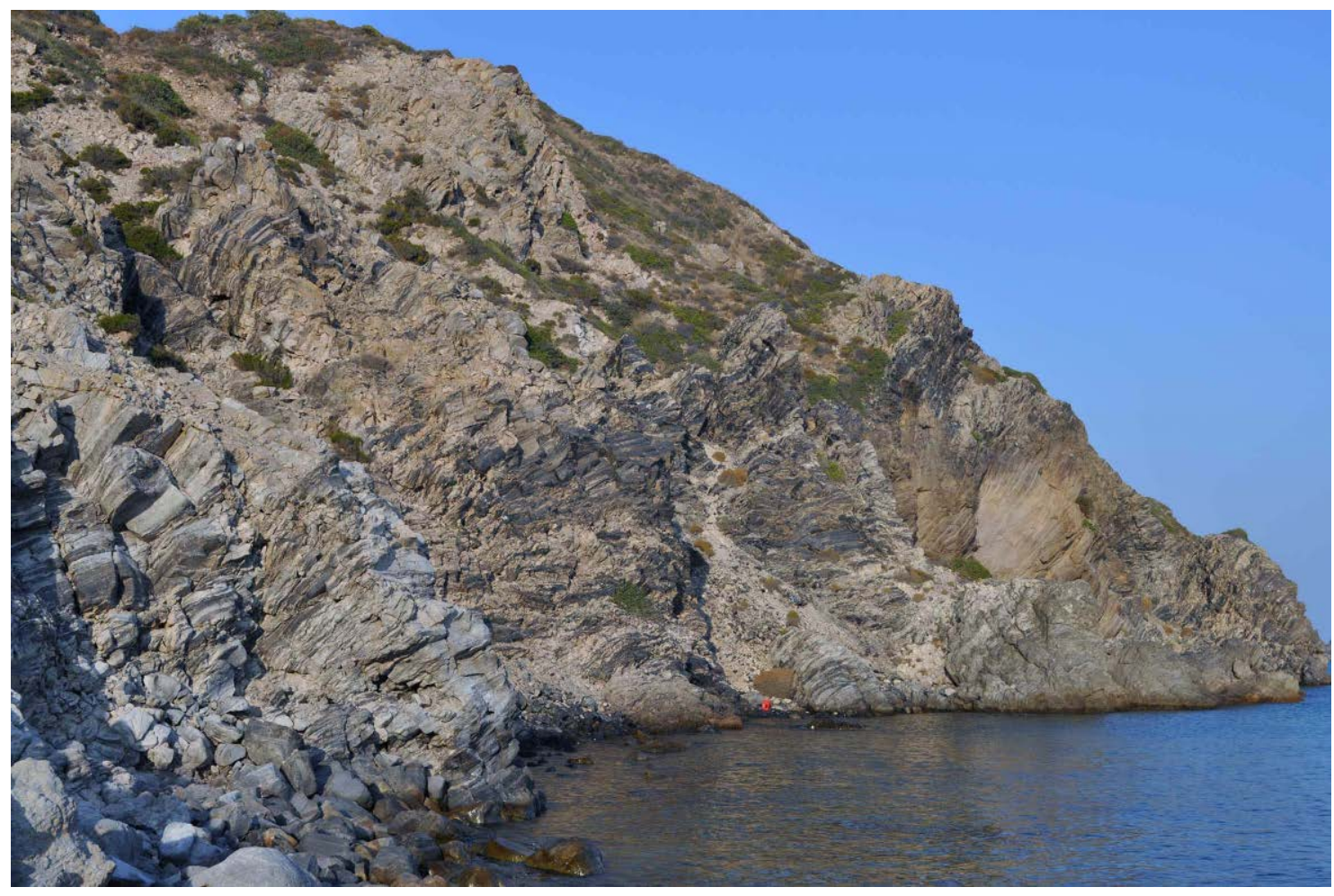

Figure 8. Obsidian exposed in the coastal cliffs at the north end of the beach on the east side of the island's neck at sampling location Giali VI.

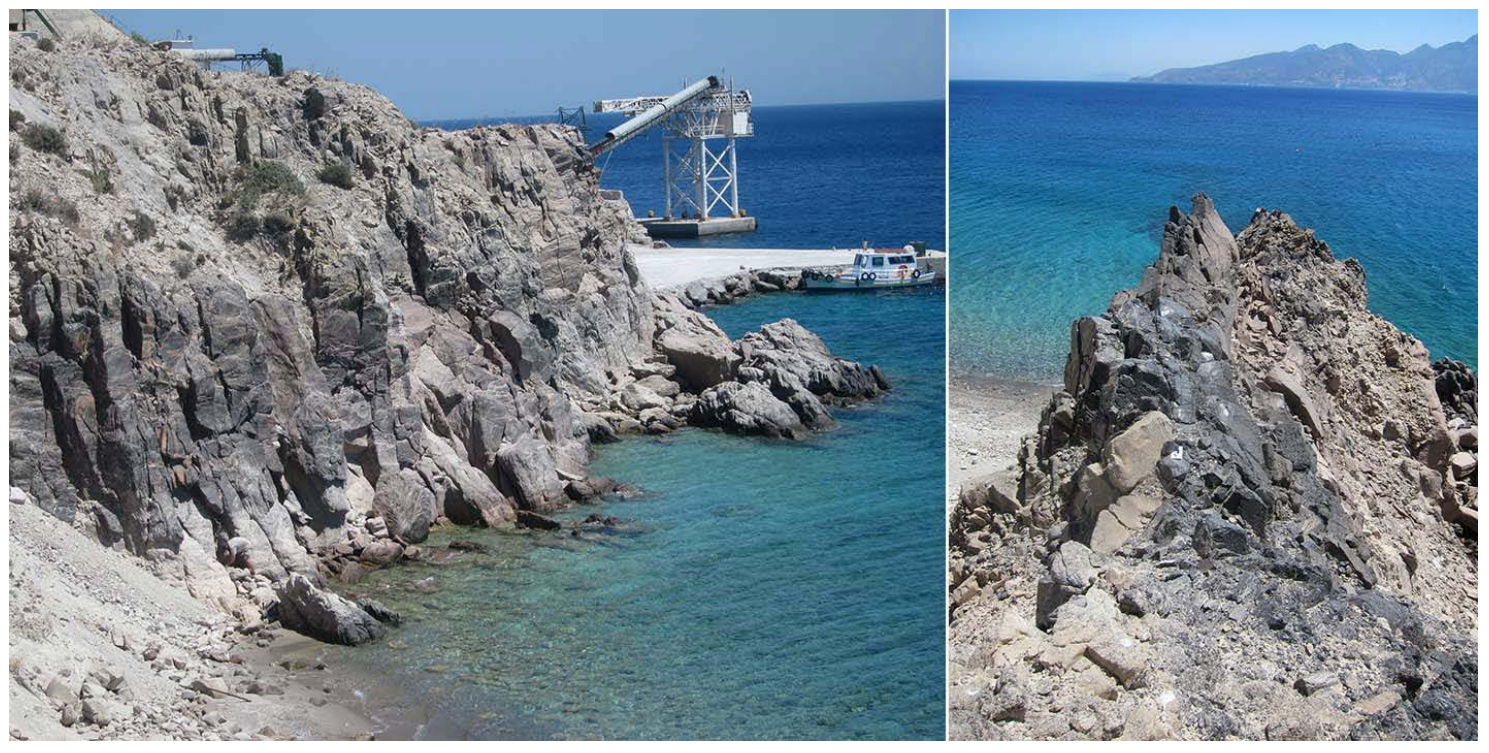

Figure 9. (left and right) Coastal exposures of spherulitic black obsidian at sampling location Giali IX. 


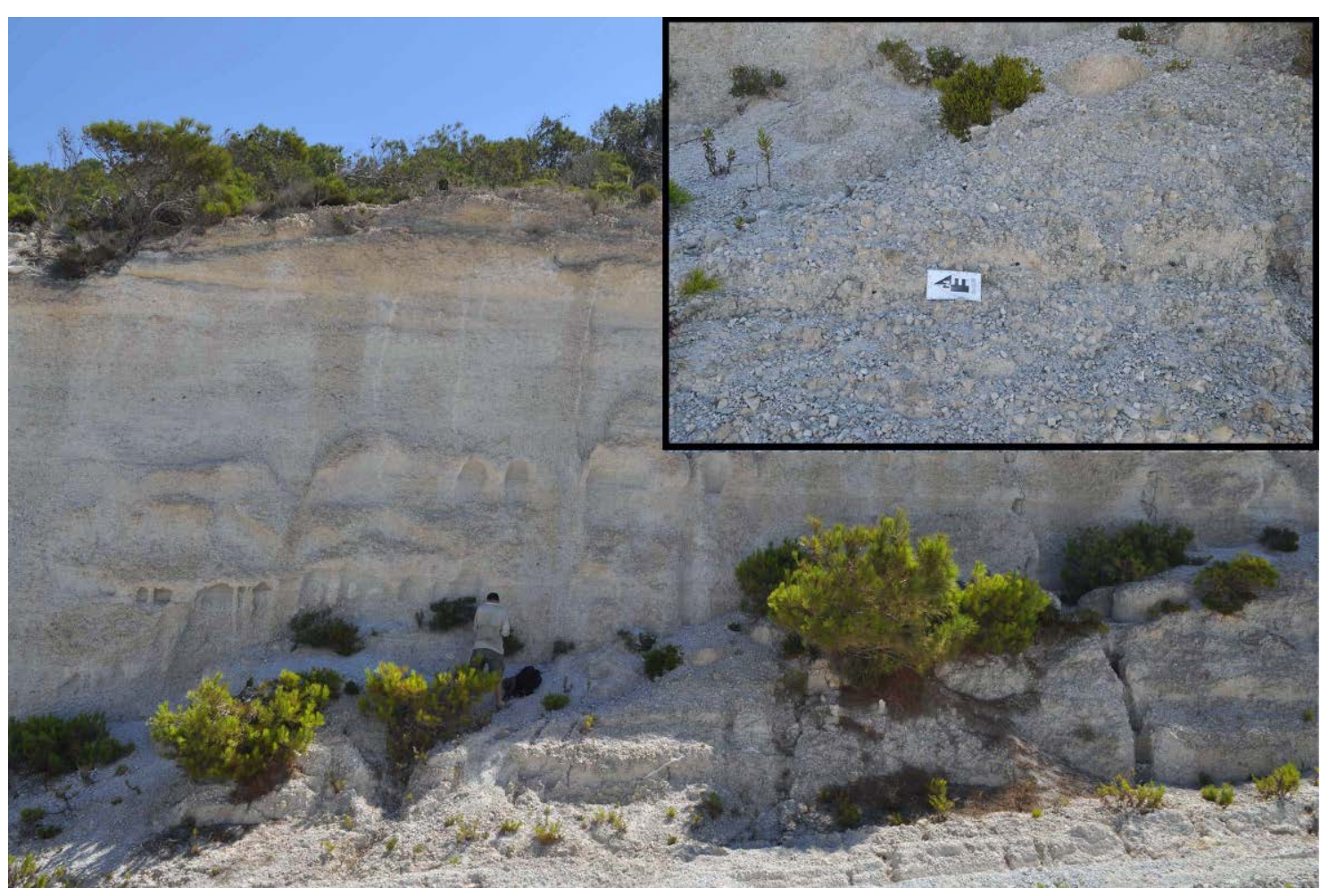

Figure 10. Occasional small $(<3 \mathrm{~cm})$ rounded nodules of obsidian in a matrix of pumice (inset), visible in a roadcut on the island's southwestern half at sampling location Giali XI.

previous investigators noted any direct evidence of exploitation-we suggest that the material is simply too readily available to have required mining that left scars or pits, and knapped too rarely to have left any notable quantities of debitage.

As noted by Bassiakos et al (2005), obsidian can also be found on the southwestern part of Giali; here we documented small, rounded nodules (usually $\leq 3 \mathrm{~cm}$ ) occurring sporadically within a matrix of pumice (Figure 10). This part of the island is heavily disturbed by mining. Geological material was collected from a single sampling station (Giali XI).

\section{The Elemental Characterization of Giali Obsidian}

The elemental characterization of Giali source materials involved the analysis of 76 samples from 11 sampling locations (Giali I-VI, VIII-
XII). The samples were analyzed non-destructively at the MAX Lab by a Thermo Scientific ARL Quant'X EDXRF spectrometer; the details of analytical procedures are provided online (see Appendix). XRF techniques are well established within Aegean / Eastern Mediterranean obsidian characterization studies, capable of discriminating the raw materials of those sources known to have been used in prehistory (e.g., Carter $e t$ al. 2013; Milić 2014). Each analytical run included the analysis of USGS standard RGM-2 to check machine calibration and accuracy, and to allow data normalization; the major and trace elemental concentrations of the geological samples and standard are reported in Table 2.

\section{Results}

A bivariate plot (Figure 11) of the trace elements strontium $(\mathrm{Sr})$ vs. zirconium $(\mathrm{Zr})$ clearly discriminates Giali obsidian from the other obsidians 
Table 2. Elemental composition of Giali obsidian as determined by EDXRF at the MAX Lab.

\begin{tabular}{|c|c|c|c|c|c|c|c|c|c|c|c|c|c|c|c|}
\hline Source & Sample & $T i$ & $M n$ & $F e$ & $Z n$ & $R b$ & $S r$ & $Y$ & $Z r$ & $N b$ & $B a$ & $\mathrm{~Pb}$ & $T h$ & $R b / Z r$ & $\begin{array}{l}M n / \\
Z r\end{array}$ \\
\hline Giali A & Giali I.001 & 1062 & 285 & 9071 & 30 & 132 & 75 & 19 & 106 & 13 & 1039 & 19 & 7 & 1.24 & 2.69 \\
\hline Giali A & Giali I.002 & 1104 & 278 & 9494 & 37 & 144 & 63 & 15 & 106 & 11 & 1035 & 23 & 12 & 1.36 & 2.63 \\
\hline Giali A & Giali I.003 & 1229 & 328 & 10185 & 38 & 154 & 72 & 19 & 113 & 12 & 1080 & 31 & 14 & 1.36 & 2.90 \\
\hline Giali A & Giali I.004 & 1093 & 299 & 9143 & 22 & 134 & 75 & 19 & 105 & 14 & 1097 & 27 & 11 & 1.29 & 2.86 \\
\hline Giali A & Giali I.005 & 1124 & 311 & 9724 & 30 & 147 & 63 & 17 & 106 & 16 & 1027 & 26 & 19 & 1.39 & 2.93 \\
\hline Giali A & Giali I.006 & 1076 & 294 & 10004 & 23 & 154 & 67 & 21 & 108 & 18 & 1157 & 30 & 17 & 1.42 & 2.71 \\
\hline Giali A & Giali I.007 & 1065 & 283 & 9325 & 32 & 138 & 73 & 20 & 110 & 13 & 1072 & 24 & 15 & 1.25 & 2.57 \\
\hline Giali A & Giali I.008 & 983 & 276 & 9001 & 26 & 134 & 63 & 20 & 100 & 16 & 1031 & 23 & 11 & 1.33 & 2.75 \\
\hline Giali A & Giali I.009 & 1118 & 280 & 9161 & 37 & 140 & 68 & 16 & 107 & 13 & 1122 & 20 & 13 & 1.31 & 2.61 \\
\hline Giali A & Giali I.010 & 1146 & 278 & 9647 & 27 & 145 & 68 & 17 & 109 & 16 & 1084 & 25 & 16 & 1.33 & 2.55 \\
\hline Giali A & Giali I.011 & 1011 & 272 & 9246 & 25 & 137 & 65 & 21 & 109 & 19 & 1101 & 24 & 12 & 1.26 & 2.50 \\
\hline Giali A & Giali I.012 & 1028 & 274 & 8804 & 32 & 135 & 63 & 17 & 107 & 15 & 1253 & 25 & 18 & 1.26 & 2.56 \\
\hline Giali A & Giali II.001 & 1092 & 291 & 9513 & 27 & 141 & 71 & 19 & 110 & 14 & 1134 & 26 & 14 & 1.29 & 2.65 \\
\hline Giali A & Giali II.002 & 1054 & 286 & 9755 & 30 & 150 & 71 & 17 & 107 & 13 & 1055 & 26 & 15 & 1.39 & 2.66 \\
\hline Giali A & Giali II.003 & 997 & 280 & 9018 & 36 & 141 & 68 & 19 & 105 & 16 & 1063 & 22 & 20 & 1.34 & 2.67 \\
\hline Giali A & Giali II.004 & 1089 & 292 & 9168 & 37 & 141 & 64 & 16 & 108 & 10 & 1016 & 25 & 16 & 1.30 & 2.70 \\
\hline Giali A & Giali II.005 & 1195 & 320 & 10003 & 42 & 156 & 70 & 17 & 110 & 19 & 1037 & 26 & 17 & 1.42 & 2.91 \\
\hline Giali A & Giali III.001 & 1113 & 313 & 8755 & 31 & 150 & 66 & 19 & 112 & 24 & 1214 & 23 & 24 & 1.33 & 2.79 \\
\hline Giali A & Giali III.002 & 994 & 287 & 7588 & 26 & 140 & 68 & 18 & 108 & 20 & 1249 & 22 & 18 & 1.30 & 2.67 \\
\hline Giali A & Giali III.003 & 1055 & 275 & 7771 & 25 & 138 & 75 & 18 & 110 & 21 & 1356 & 21 & 17 & 1.25 & 2.49 \\
\hline Giali A & Giali III.004 & 1157 & 323 & 9381 & 28 & 153 & 69 & 20 & 119 & 21 & 1161 & 23 & 24 & 1.28 & 2.71 \\
\hline Giali A & Giali III.005 & 1141 & 303 & 9046 & 30 & 148 & 72 & 16 & 111 & 17 & 1072 & 22 & 22 & 1.33 & 2.72 \\
\hline Giali A & Giali IV.001 & 1216 & 289 & 9805 & 38 & 146 & 75 & 18 & 118 & 14 & 1388 & 29 & 21 & 1.24 & 2.45 \\
\hline Giali A & Giali IV.002 & 986 & 253 & 9188 & 28 & 130 & 66 & 16 & 103 & 23 & 1108 & 19 & 19 & 1.27 & 2.47 \\
\hline Giali A & Giali IV.003 & 1106 & 312 & 9738 & 32 & 140 & 76 & 18 & 105 & 14 & 1257 & 24 & 22 & 1.34 & 2.98 \\
\hline Giali A & Giali IV.004 & 1026 & 278 & 9107 & 37 & 139 & 69 & 18 & 103 & 11 & 1352 & 19 & 13 & 1.34 & 2.69 \\
\hline Giali A & Giali IV.005 & 1053 & 264 & 9374 & 29 & 145 & 68 & 20 & 107 & 18 & 1151 & 22 & 21 & 1.36 & 2.48 \\
\hline Giali A & Giali IV.006 & 1066 & 283 & 9646 & 32 & 137 & 65 & 15 & 102 & 11 & 1325 & 25 & 21 & 1.34 & 2.77 \\
\hline Giali A & Giali V.001 & 1005 & 306 & 9559 & 36 & 138 & 71 & 20 & 99 & 19 & 1124 & 29 & 10 & 1.39 & 3.09 \\
\hline Giali A & Giali V.002 & 1057 & 287 & 9159 & 30 & 136 & 72 & 16 & 101 & 11 & 1425 & 24 & 20 & 1.35 & 2.84 \\
\hline Giali A & Giali V.003 & 1289 & 310 & 10626 & 30 & 149 & 80 & 18 & 119 & 15 & 1338 & 28 & 19 & 1.25 & 2.62 \\
\hline Giali A & Giali V.004 & 1076 & 278 & 9031 & 37 & 141 & 63 & 17 & 102 & 12 & 1401 & 20 & 14 & 1.37 & 2.72 \\
\hline Giali A & Giali V.005 & 1038 & 260 & 8833 & 21 & 131 & 67 & 20 & 101 & 17 & 1113 & 24 & 10 & 1.30 & 2.59 \\
\hline Giali A & Giali VI.001 & 1081 & 272 & 8708 & 38 & 127 & 67 & 19 & 99 & 12 & 1288 & 23 & 8 & 1.28 & 2.74 \\
\hline Giali A & Giali VI.002 & 949 & 248 & 8675 & 32 & 133 & 67 & 15 & 99 & 13 & 1337 & 21 & 16 & 1.34 & 2.50 \\
\hline Giali A & Giali VI.003 & 1024 & 273 & 8869 & 37 & 132 & 64 & 16 & 99 & 13 & 1290 & 22 & 20 & 1.34 & 2.76 \\
\hline Giali A & Giali VI.004 & 1086 & 317 & 9762 & 29 & 151 & 62 & 20 & 111 & 16 & 1115 & 25 & 16 & 1.36 & 2.85 \\
\hline Giali A & Giali VI.005 & 995 & 275 & 9080 & 42 & 127 & 58 & 21 & 101 & 11 & 1037 & 26 & 13 & 1.26 & 2.71 \\
\hline Giali A & Giali VI.006 & 1028 & 261 & 9489 & 27 & 143 & 73 & 17 & 112 & 25 & 1191 & 20 & 25 & 1.28 & 2.34 \\
\hline Giali A & Giali VIII.001 & 1121 & 304 & 8425 & 31 & 145 & 73 & 18 & 110 & 22 & 1229 & 22 & 18 & 1.31 & 2.75 \\
\hline Giali A & Giali VIII.002 & 1122 & 309 & 8112 & 29 & 142 & 71 & 19 & 111 & 22 & 1270 & 21 & 19 & 1.28 & 2.78 \\
\hline
\end{tabular}




\begin{tabular}{|c|c|c|c|c|c|c|c|c|c|c|c|c|c|c|c|}
\hline Source & Sample & $T i$ & $M n$ & $\mathrm{Fe}$ & $Z n$ & $R b$ & $S r$ & $Y$ & $Z r$ & $\mathrm{Nb}$ & $B a$ & $P b$ & Th & $R b / Z r$ & $\begin{array}{l}M n / \\
Z r\end{array}$ \\
\hline Giali A & ali & 81 & 319 & 5 & 30 & 148 & 79 & 20 & 116 & 23 & 1324 & 22 & 21 & 1.28 & 2.75 \\
\hline Giali A & Giali VIII.004 & 1131 & 301 & 303 & 29 & 148 & 71 & 17 & 111 & 20 & 251 & 22 & 18 & 1.33 & 2.71 \\
\hline Giali A & Giali IX.001 & 1127 & 289 & 8782 & 30 & 167 & 69 & 19 & 116 & 17 & 1194 & 25 & 20 & 1.44 & 2.50 \\
\hline Giali A & Giali IX.002 & 1043 & 257 & 7790 & 28 & 141 & 79 & 18 & 114 & 18 & 1263 & 24 & 24 & 1.24 & 2.26 \\
\hline Giali A & Giali IX.003 & 1156 & 312 & 8820 & 41 & 148 & 73 & 18 & 113 & 21 & 1127 & 22 & 19 & 1.31 & 2.77 \\
\hline Giali A & Giali IX.004 & 1098 & 288 & 7977 & 29 & 141 & 67 & 19 & 115 & 21 & 1308 & 21 & 16 & 1.23 & 2.51 \\
\hline Giali A & Giali IX.005 & 1088 & 318 & 9188 & 31 & 145 & 73 & 18 & 112 & 21 & 1030 & 22 & 23 & 1.29 & 2.84 \\
\hline Giali A & Giali IX.006 & 1124 & 307 & 8653 & 32 & 145 & 72 & 20 & 116 & 20 & 1236 & 22 & 20 & 1.25 & 2.65 \\
\hline Giali A & Giali IX.007 & 1094 & 289 & 7954 & 25 & 145 & 62 & 17 & 111 & 16 & 1394 & 23 & 25 & 1.31 & 2.61 \\
\hline Giali A & Giali IX.008 & 1073 & 282 & 8749 & 26 & 147 & 78 & 19 & 115 & 15 & 1106 & 23 & 27 & 1.28 & 2.46 \\
\hline Giali A & Giali IX.009 & 1159 & 317 & 8978 & 29 & 157 & 68 & 17 & 116 & 16 & 1195 & 26 & 29 & 1.35 & 2.72 \\
\hline Giali A & Giali X.001 & 1148 & 259 & 8477 & 34 & 147 & 74 & 17 & 112 & 17 & 1276 & 24 & 19 & 1.31 & 2.31 \\
\hline Giali A & Giali X.002 & 1094 & 267 & 8286 & 27 & 147 & 68 & 19 & 111 & 19 & 1292 & 24 & 24 & 1.33 & 2.41 \\
\hline Giali A & Giali X.003 & 1082 & 271 & 8290 & 27 & 142 & 70 & 19 & 114 & 16 & 1248 & 25 & 21 & 1.25 & 2.38 \\
\hline Giali A & Giali X.004 & 1081 & 252 & 8062 & 29 & 142 & 71 & 18 & 114 & 16 & 1250 & 24 & 21 & 1.25 & 2.21 \\
\hline Giali B & Giali XI.001 & 1049 & 271 & 8699 & 31 & 135 & 67 & 18 & 118 & 18 & 1250 & 23 & 18 & 1.14 & 2.30 \\
\hline Giali B & Giali XI.002 & 1039 & 274 & 8360 & 29 & 135 & 67 & 20 & 113 & 18 & 1338 & 23 & 21 & 1.19 & 2.42 \\
\hline Giali B & Giali XI.003 & 1116 & 291 & 9071 & 33 & 137 & 70 & 19 & 114 & 18 & 1308 & 23 & 21 & 1.20 & 2.55 \\
\hline Giali B & Giali XI.004 & 1091 & 274 & 8781 & 33 & 131 & 67 & 18 & 112 & 16 & 1254 & 23 & 21 & 1.17 & 2.46 \\
\hline Giali B & Giali XI.005 & 1068 & 286 & 9033 & 32 & 135 & 68 & 20 & 113 & 17 & 1290 & 24 & 19 & 1.20 & 2.53 \\
\hline Giali B & Giali XI.006 & 1057 & 289 & 8601 & 32 & 132 & 66 & 19 & 113 & 18 & 1263 & 23 & 19 & 1.17 & 2.56 \\
\hline Giali B & Giali XI.007 & 1114 & 289 & 9062 & 30 & 137 & 68 & 18 & 113 & 17 & 1287 & 24 & 20 & 1.21 & 2.55 \\
\hline Giali B & Giali XI.008 & 1044 & 287 & 8761 & 29 & 134 & 70 & $1 s$ & 115 & 18 & 1342 & 22 & 19 & 1.16 & 2.50 \\
\hline Giali B & Giali XII.001 & 1066 & 300 & 8716 & 34 & 133 & 67 & 18 & 110 & 20 & 1231 & 23 & 17 & 1.21 & 2.73 \\
\hline Giali B & Giali XII.002 & 1099 & 292 & 8371 & 48 & 129 & 65 & 19 & 107 & 21 & 1266 & 21 & 16 & 1.20 & 2.73 \\
\hline Giali B & Giali XII.003 & 1126 & 306 & 8686 & 45 & 131 & 64 & 18 & 111 & 19 & 1310 & 22 & 16 & 1.18 & 2.75 \\
\hline Giali B & Giali XII.004 & 1074 & 288 & 8424 & 38 & 128 & 64 & 19 & 110 & 21 & 1289 & 22 & 13 & 1.17 & 2.62 \\
\hline Giali B & Giali XII.005 & 1048 & 299 & 8593 & 33 & 129 & 64 & 18 & 108 & 20 & 1309 & 23 & 15 & 1.19 & 2.76 \\
\hline Giali B & Giali XII.006 & 1088 & 285 & 8151 & 43 & 127 & 63 & 18 & 107 & 19 & 1308 & 22 & 20 & 1.18 & 2.66 \\
\hline Giali B & Giali XII.007 & 1119 & 312 & 9304 & 42 & 139 & 67 & 18 & 114 & 22 & 1306 & 23 & 19 & 1.22 & 2.74 \\
\hline Giali B & Giali XII.008 & 1073 & 303 & 8756 & 46 & 131 & 67 & 19 & 109 & 19 & 1197 & 23 & 15 & 1.20 & 2.78 \\
\hline Giali B & Giali XII.009 & 1220 & 307 & 9297 & 51 & 130 & 65 & 18 & 111 & 20 & 1251 & 23 & 16 & 1.18 & 2.78 \\
\hline Giali B & Giali XII.010 & 1056 & 278 & 8045 & 50 & 124 & 62 & 17 & 107 & 20 & 1267 & 22 & 13 & 1.16 & 2.60 \\
\hline Giali B & Giali XII.011 & 1144 & 295 & 8785 & 65 & 128 & 63 & 18 & 108 & 19 & 1227 & 21 & 17 & 1.19 & 2.73 \\
\hline Giali B & Giali XII.012 & 1083 & 301 & 8381 & 43 & 130 & 65 & 18 & 112 & 20 & 1313 & 22 & 19 & 1.16 & 2.68 \\
\hline RGM-2 & Average $(\mathrm{n}=11)$ & 1480 & 308 & 13493 & 38 & 147 & 105 & 24 & 225 & 9 & 865 & 23 & 12 & 0.65 & 1.37 \\
\hline RGM-2 & St. Dev & 108.4 & 23.3 & 595.2 & 3.7 & 2.3 & 2.8 & 1.9 & 9.1 & 1.5 & 154.5 & 2.1 & 3.1 & 0.02 & 0.07 \\
\hline RGM-2 & \% St. Dev & 7.32 & 7.59 & 4.41 & 9.61 & 1.58 & 2.63 & 7.82 & 4.03 & 16.47 & 17.87 & 9.05 & 25.46 & 2.77 & 4.95 \\
\hline
\end{tabular}




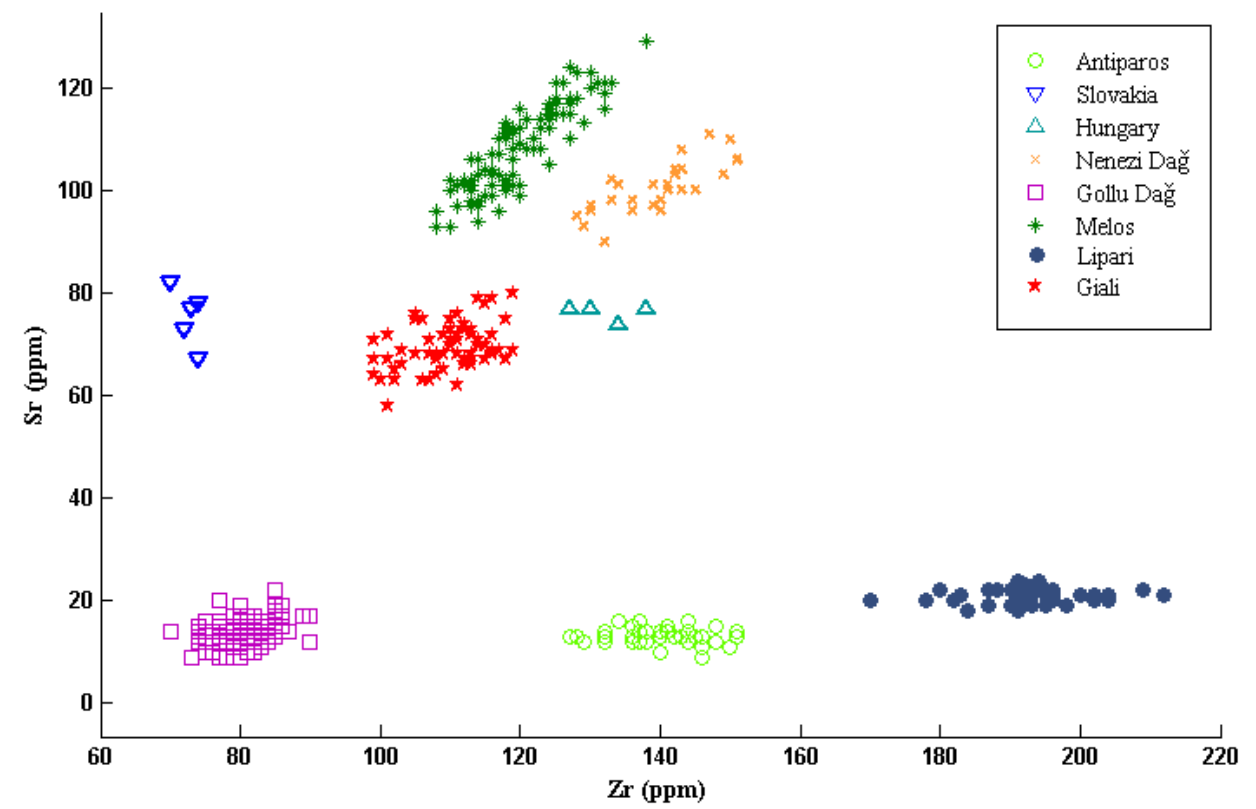

Figure 11. Bivariate Sr vs. Zr contents plot for obsidian from Aegean, Carpathian, central Anatolian, and Lipari sources (ppm = parts per million).

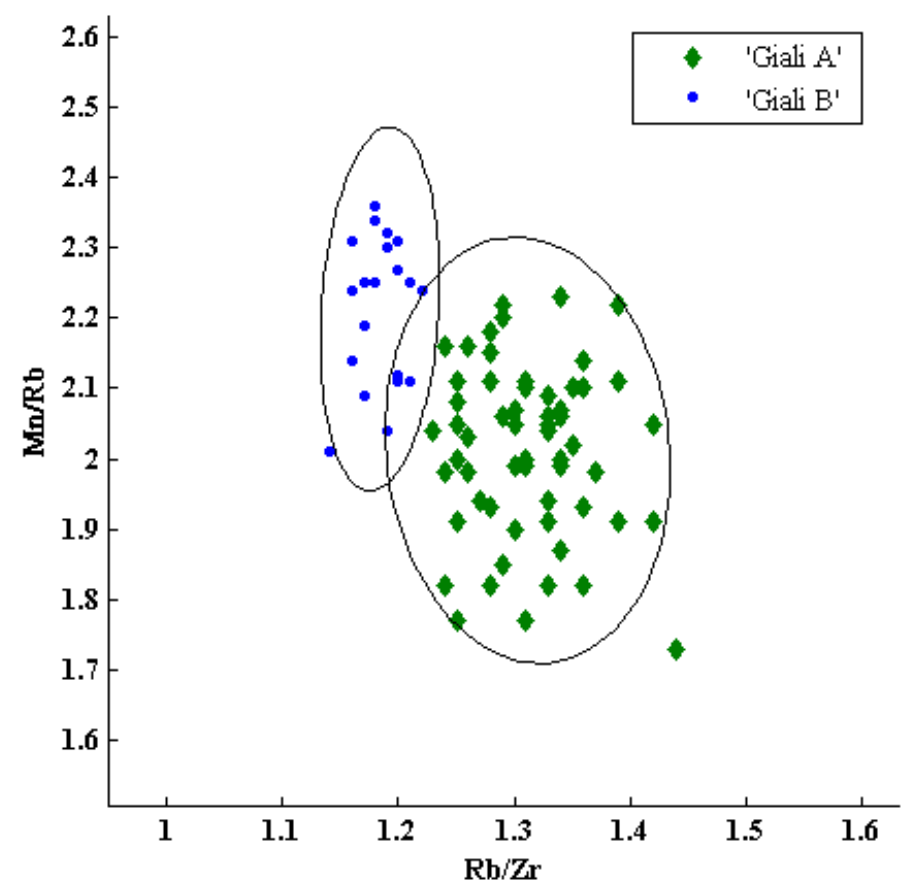

Figure 12. Bivariate plot of ratios of concentrations in $\mathrm{ppm}$ of $\mathrm{Rb} / \mathrm{Zr}$ vs. $\mathrm{Mn} / \mathrm{Rb}$ with $95 \%$ confidence ellipses of the two Giali groups. 
used by prehistoric Aegean populations (Carter and Kilikoglou 2007; Bellot-Gurlet et al. 2008; Milić 2014). In turn, by plotting elemental ratios, specifically manganese $(\mathrm{Mn}) / \mathrm{Zr}$ vs. rubidium (Rb)/Zr, (Figure 12), it was possible to distinguish two source groups that we name 'Giali A' (Giali I-VI, VIII-X) and 'Giali B' (Giali XI, $\mathrm{XII}$ ); a result verified by a discriminant function analysis (see Appendix for details of online supplementary data).

The chemical signature for Giali A obsidian relates to the well-known lustrous black and spherulitic raw materials from the island's northeast (Figures 4 [top], 5-9, 13 [top]). The Giali B source is comprised of the obsidian ( $\mathrm{n}=8)$ collected from the southwest part of the island (Giali $\mathrm{XI}$ ), and the beach location (Giali XII) on the southern shore of the island's neck (Figures 2-3). This material can be visually distinguished from Giali A obsidian on the basis of its homogeneity; it lacks the white spherulites and is black, glassy, and relatively translucent (Figure 13 [bottom]). The distinct chemical and magnetic properties of the obsidian from the southern beach were previously noted by Cherry et al. (n.d. ['Area h']), and McDougall et al. (1983: 447, fig. 3), while the southwestern source material was first referenced by Bassiakos et al. (2005).

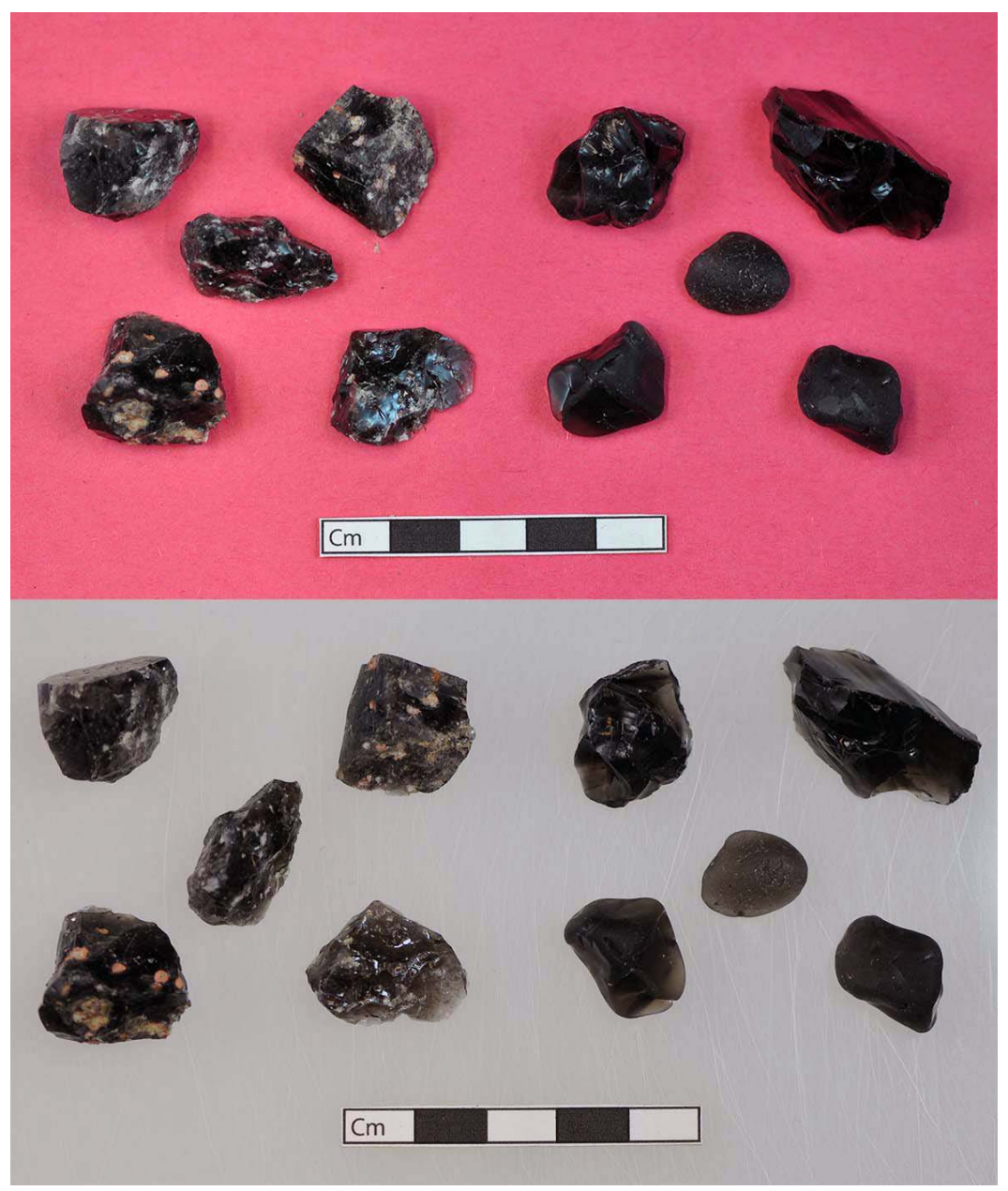

Figure 13. (left) Flakes and natural nodules of Giali A obsidian; (right) Giali B obsidian. Upper image: incident light; lower image: transmitted light. 


\section{The Exploitation of Giali A Obsidian Through Time}

A diachronic review of Giali obsidian's use by prehistoric populations provides the context within which the material's exploitation can be understood. At present the sole known use of Giali B obsidian comes from the FN village on Giali itself (Bassiakos et al 2005). As such, this section is dedicated to discussing the circulation and consumption of Giali A obsidian including material recognized visually and/or archaeometrically. While we detail general trends in how and where the raw material(s) were being used through time, this is not intended to be an exhaustive account of sites where Giali A obsidian has been found.

\section{Mesolithic (Ninth to Eighth Millennium Cal BC)} While recent discoveries have suggested that the Aegean basin might have been occupied at least intermittently from the Lower Palaeolithic (Runnels 2014), the earliest that the major deposits of obsidian (Giali A) could have been exploited (given its formation date range of 24-30 ka) is the Upper Palaeolithic of the later Pleistocene (Bigazzi and Radi 1981). At present there is no evidence for its use prior to the Early Holocene. This Giali A material-sourced on the basis of its distinctive visual appearancewas found at the Mesolithic site of Kerame 1 on the island of Ikaria, $130 \mathrm{~km}$ north of the source (Figure 14.A), a settlement that should date to the ninth to eighth millennium Cal $\mathrm{BC}$ based on the comparability of its lithics to well-dated material elsewhere in the Aegean (Sampson et al. 2012). At Kerame 1 obsidian from Giali and Melos was used to make flake tools from multidirectional cores, the occasional blade, and tools including denticulates and scrapers (Sampson $e t$ al. 2012: 19-33, fig. 13). It is important to note that despite its comparatively poorer knapping quality, Giali A obsidian, which comprised 15\% of the assemblage, was worked in the same manner as local cherts and Melian obsidian.
Neolithic (Seventh to Fourth Millennium Cal BC) There is only one reference to Giali A obsidian from the Early Neolithic (EN), namely two 'flakes' from Knossos on Crete, where it comprises a mere $0.3 \%$ of the Knossian EN I chipped stone assemblage (J. Conolly, pers. comm.). The material was sourced chemically (Evans 1994: 5, n. 10), and dates ca. 6500/6400-5900 вС (Tomkins 2008: 30-33, table 3.1). Given how few sites of this date are known from the southern Aegean, Giali obsidian's apparent EN rarity should be treated with caution.

The Late Neolithic (LN) and FN periods of the fifth to fourth millennium $\mathrm{BC}$ witnessed a major expansion in the exploitation of Giali A obsidian by Dodecanesian populations in particular (Figure 14.B). The material has been visually recognized at a number of LN-FN sites on Kos and Rhodes (Aspri Petra and Kalythies caves), Alimnia, Leros, Kalimnos, Karpathos, and Tilos (Sampson 1984; 1987; Georgiadis 2008; 2011). Quantified data are limited, although Giali A obsidian is said to comprise $91 \%$ of the chipped stone from a series of LN-FN survey sites on neighboring Kos (Melian obsidian constituted 3\% [Georgiadis 2011: 95-101]).

Outside the Dodecanese, the amount of Giali A obsidian circulating decreases sharply, with only handfuls reported from the LN-FN Cyclades, Crete, and western Anatolia (Figure 14.B), where populations usually relied on Melian obsidian for tool manufacture (Carter 2009). The difference in community procurement traditions is particularly noticeable as one moves from Karpathos, $85 \mathrm{~km}$ from the source in the southern Dodecanesewhere Giali A obsidian is recurrently attested at LN-FN sites (Nowicki 2014: 298) — to neighboring Crete, some $75 \mathrm{~km}$ further away, where the material is rare if not completely absent from fifth- to fourth-millennium settlements. From Crete's eastern coast, closest to Giali, only a single surface find has been documented from FN Itanos (Nowicki 2014: 299), and none has been recovered from the nearby Pelikata Cave (T. Carter, personal observation). Further west, there are no 


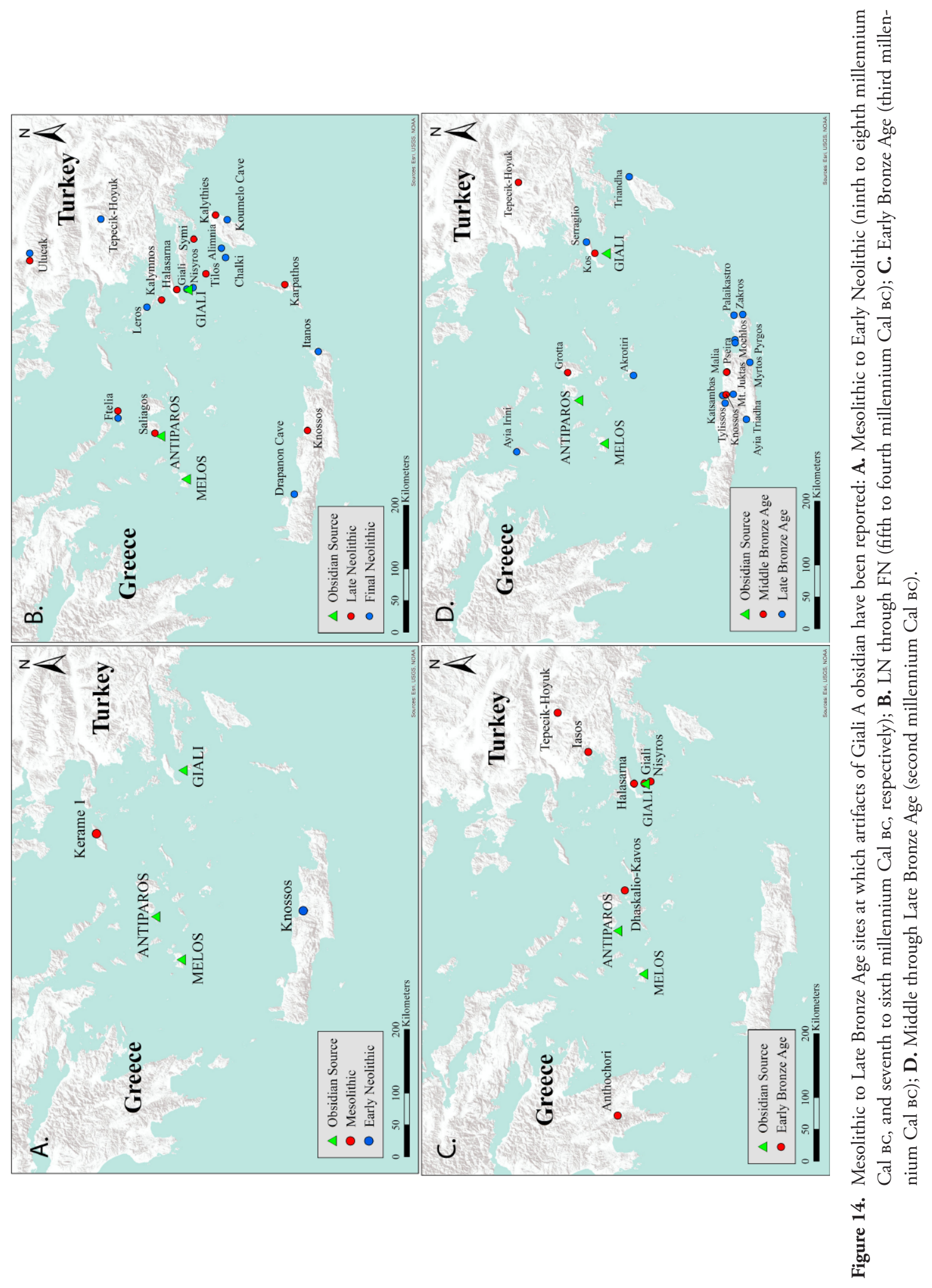


reports of Giali A obsidian from well-connected FN Kephala-Petras (D'Annibale 2008), while even at Knossos there is only a single 'flake' reported from an LN II deposit (Evans 1994: 5, n. 10 [originally referred to as EN II-Tomkins 2008]). In the Cyclades the material is even rarer, absent from LN-FN Ftelia on Mykonos (Galanidou 2002: 159) and FN Kephala on Kea (Coleman 1977). Only at the LN (fifth millennium) village of Saliagos near Antiparos were four 'waste flakes' of Giali A obsidian documented (one chemically); these items comprise a minute proportion of the assemblage $(0.02 \%)$, while the other 24,000 pieces are Melian obsidian (Cann et al. 1968). In the opposite direction Giali A obsidian seems to be as rare in western Anatolia as it is in the Cyclades and Crete (N. Kolankaya Bostanc1, pers. comm.), only apparent thus far in very small quantities $(\leq 1 \%)$ from the fifth- to fourth-millennium BC settlements of Tepecik Höyük (T. Carter, personal observation) and Ulucak (M. Milić pers. comm.).

During the LN-FN, Giali A obsidian seems to have been used by all of these communities to make rudimentary percussion-knapped flake tools, together with lesser quantities of blades. Formal retouched tools are rarely reported (though modification can be difficult to see), but scrapers, sickles, and an arrowhead are mentioned from survey sites on Kos (Georgiadis 2011: 97-98, 145-49, fig. 18, pl. 14).

On Giali itself, there is evidence for the island finally being colonized in the FN (fourth millennium $\mathrm{Cal} \mathrm{BC}$ ), with the establishment of a small agro-pastoral community and a cemetery of 70 graves (Sampson 1988). Archaeometric analyses have shown that this population was exploiting both of the island's obsidian sources for tool-making; this is currently the only proven use of Giali B obsidian in prehistory (Bassiakos et al. 2005). The local potters also used obsidian (whether Giali A or B is unclear) as a temper in making both open and closed vases (Katsarou et al. 2002); it remains uncertain as to whether this fabric provided a specific functional ben- efit, such as conductivity, temperature resistance, or wall strength. Obsidian-tempered wares are known elsewhere in the southern Aegean Bronze Age (third to second millennium BC), but likely employed Melian obsidian (Vaughan 1990).

\section{Early Bronze Age (Third Millennium Cal BC)}

The Early Bronze Age (EBA) of the third millennium $\mathrm{BC}$ saw a significant reduction in the use and circulation of Giali A obsidian (Figure 14.C). With no evidence for EBA occupation on Giali, the raw material was presumably procured by expeditions from elsewhere, such as neighboring Kos, where Giali A obsidian has been documented from a number of survey sites, albeit within assemblages dominated by Melian obsidian (Georgiadis 2011: 95-101, 145-48). In western Anatolia a few pieces of Giali A obsidian are reported from EB I-II burials at Iasos (Pecorella 1984: 98), and Tepecik Höyük (T. Carter, personal observation). In the Cyclades there are only a handful of pieces from Keros, from the late EB II settlement of Dhaskalio, and the EB II 'Special Deposit South' on nearby Kavos, part of a ritually accumulated mass of fine/non-local goods (Carter and Milić 2013: 534-41, fig. 28.3). The Keros material was all in the form of unmodified flakes and/or chunks; if they represent manufacturing debris it is unclear what the end-products were. While the difference in distance from Keros to the obsidian sources on Melos and Giali is not particularly large (ca. $100 \mathrm{~km}$ and $137 \mathrm{~km}$ respectively), the latter raw material only comprises a tiny proportion of the Dhaskalio and Kavos obsidian assemblages (0.1\%).

Giali A obsidian is currently unknown from EBA Crete, while a single piece from Antichori in Laconia represents the only example from the mainland (Georgiadis 2008: 110).

\section{Middle to Late Bronze Age (Second Millennium Cal $B C$ )}

The MBA and Late Bronze Age (LBA) of the second millennium $\mathrm{BC}$ witnessed a major shift 
in the consumption and circulation of Giali A obsidian, with the raw material employed to manufacture prestige goods at the palatial centers of Knossos and Malia, the first use of this raw material by Cretans since the Neolithic (Figure 14.D). At Knossos two small nodules (both $<2$ sq cm) came from the 'Vat Room Deposit', a mix of cultic equipment and materials for making elite items dated to the early MBA (Middle Minoan [MM] IB), of the twentieth century Cal вC (Panagiotaki 1998: 180, pl. 36a; 1999: 27, 41-42, 62). Slightly later in date (MM IIB) are three pieces of Giali A obsidian (one sourced) from a metalsmith/lapidary's workshop just north of a ceremonial center in the Malia palace (Warren 1969: 136, P 627; Bellot-Gurlet et al. 2008: 422-24). The atelier produced a series of roughouts for vessel manufacture, including two blocks of steatite, one of pink quartzite, and three from Giali A, the largest a cut block of $18 \times 11.7 \mathrm{~cm}$, together with part-finished vases of steatite and marble (Chapouthier and Demargne 1942: 24, 54-55, pl. LII, 2b; Pelon 1982: 182). Due west of the palace in the Quartier Mu complex, Giali A obsidian was used to make stamp-seals at the MM II Atelier de Sceaux, as evidenced by two unfinished examples (Platon et al. 1977: nos. 129 and 130), and two waste flakes. One of the latter pieces and another flake from an MM IB sondage were chemically sourced to Giali A (Carter and Kilikoglou 2007: 124-26, fig. 5).

While the cut block from Malia suggests that Giali A obsidian was being imported to make vases as well as sealstones, there are no securely dated vessels from this period. There is however indirect evidence for Giali A obsidian's use for vase production at this time in the form of the 'white-flecked style' pottery, vessels whose black slip and white painted flecks (e.g., Macdonald and Knappett 2007: 68, fig. 3.6, 207) is skeuomorphic, clearly imitating vessels made of Giali A obsidian. This ceramic tradition began relatively early in the First Palace Period, attested in MM IB at Knossos (C. Macdonald, pers. comm.), a likely center of these pots' production.
During the 'Second Palace' or 'Neopalatial' period (ca. eighteenth to fifteenth century $\mathrm{Cal}$ BC, Middle Minoan [MM] IIIA to Late Minoan [LM] IB), there is direct evidence for Giali A obsidian being used to make both vessels and sealstones on Crete. There are chalices from the palaces of Zakros (Figures 14.D and 15.A) and Knossos, rhyta in the form of a dolium and triton shell from the large urban (or palatial) complexes at Aghia Triada and Palaikastro, bowls from Knossos and the villa of Myrtos Pyrgos, plus an offering table from the peak sanctuary at Juktas, the mountain-based ritual center connected to Knossos (Warren 1969: 135-36; Hankey 1980: 211, pl. 79, b; Betancourt 1997). There is also an unworked block (vase preform?) of Giali A obsidian from the villa at Tylissos, plus two large (> 1 cubic $\mathrm{m}$ ) boulders, one from Poros-Katsambas (on display in Herakleion Museum), the other found a few meters offshore from Pacheia Ammos in East Crete-i.e., less than $1 \mathrm{~km}$ from the palace at Gournia (T.M. Brogan, pers. comm.).

A Neopalatial building at Mochlos produced a small nodule (Figure 4 [top]) from a room where seals were being made (T. Carter, personal observation), a site that also produced a lentoid sealstone of Giali A obsidian (a surface find, possibly of Protopalatial date [Hughes and Warren 1963]). Of broadly contemporary date is a lentoid seal of Giali A obsidian with figurative decoration (warrior/lion) from the royal Mycenaean tholos tomb at Vaphio in Laconia (Xenaki-Sakellariou 1964: cat. no. 228). The only other sites where Giali A obsidian is documented at this time are island-based communities known to have strong connections with 'Minoan' Crete (Figure 14.D), including Ialysos on Rhodes (Marketou 2009), Seraglio on Kos (T. Marketou pers. comm.), and the Cycladic sites of Ayia Irini on Kea, Akrotiri on Thera, and Grotta on Naxos (Davis et al. 1983: 36566, pl. 70f; Moundrea-Agrafioti 1990: 391-92). LBA activity on Giali itself is evidenced directly by an LB I ceramic assemblage excavated from 


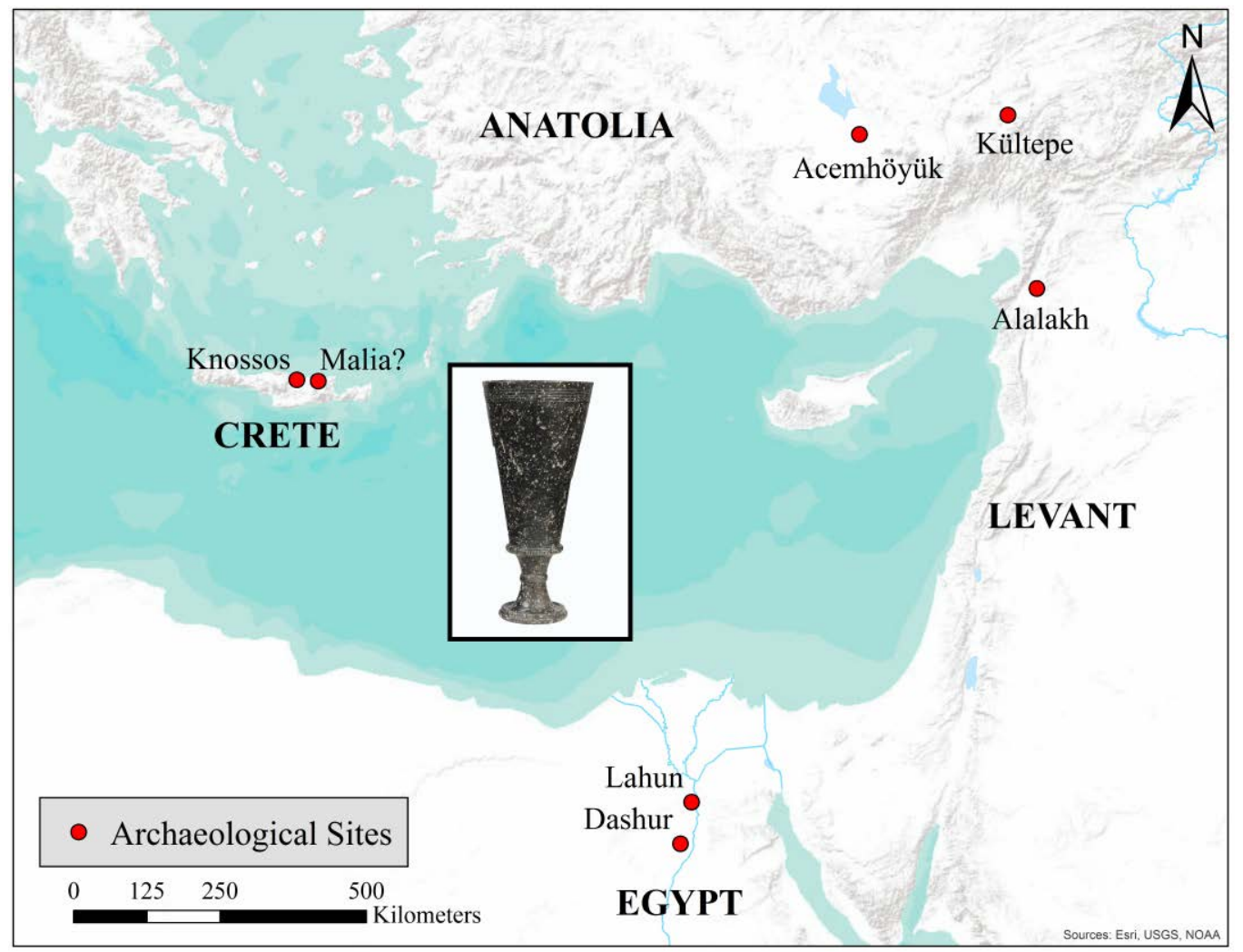

Figure 15. Middle Bronze Age (early second millennium Cal вс) Eastern Mediterranean sites at which obsidian vessels are found and/or produced; (inset) Late Minoan IB chalice of Giali A obsidian from the palace at Zakros (HM 2725), height $28.6 \mathrm{~cm}$, diameter $13.25 \mathrm{~cm}$. Image reproduced courtesy of the Heraklion Archaeological Museum.

the western side of the island's neck; the excavated vessels attest to links with Seraglio on Kos (Sampson and Liritzis 1998: 104, fig. 14).

The Neopalatial period represents both the apogee and final period of Giali A obsidian's use on Crete, with no artifacts of this material securely dated to the subsequent 'Final Palace' phase, though Evans (1901-1902: 123) does mention fragmentary sealstone from 'the latest' period of the palace at Knossos.

\section{Discussion: The Significance of Giali Obsid- ian Consumption Through Time}

This survey of the obsidian sources on Giali, the elemental characterization of its products, and overview of the raw material's consumption through time and space, serve to summarize the current state of knowledge about Giali obsidian. Our work confirms that the well-known deposits of the black, lustrous, and highly spherulitic obsidian on the northeastern half of the island constitute the primary deposits of archaeological significance; we refer to this source as 'Giali A'. Here, the obsidian is available in the form of easily accessible large boulders and exposed flows. This material derives from an eruptive event of late Pleistocene date, ca. 24-30 ka, whereby this obsidian could only ever have been used from the later Palaeolithic onwards. Current evidence suggests that it was exploited by various Aegean populations from the Lower 
Mesolithic to LB I-i.e., the first half of the ninth to the later second millennium $\mathrm{Cal}$ вс. To date only Giali A obsidian is known-in part through characterization studies, but mainly on the basis of visual identification - to have been used by off-island populations. On the southwestern half of the island, we follow Bassiakos et al. (2005) in documenting another source'Giali B' - that is quite distinct geologically and chemically. This obsidian, a product of an earlier Pleistocene volcanic eruption, is black, lustrous, relatively translucent, largely inclusion-free, and has a far superior knapping quality. It is, however, only present in small nodules (mainly $\leq 3 \mathrm{~cm}$ ), which would have significantly limited its utility for tool-making. That said, given the microlithic character of Aegean Mesolithic assemblages (Kaczanowksa and Kozlowski 2014), it is not inconceivable that some of the obsidian artifacts from Kerame 1 on Ikaria were made of Giali B obsidian, particularly as Giali A products were well-represented there. This hypothesis could be tested through an elemental characterization study.

During the early Mesolithic to EBA periods (ninth to third millennium Cal BC), Giali A obsidian was exploited primarily by Dodecanesian communities, most of whom lived within a $60-\mathrm{km}$ radius of the source, with only tiny quantities being accessed by Cycladic, Cretan, and western Anatolian populations (Figure 14.A-C). Throughout this region in the Mesolithic (if the Kerame 1 assemblage is representative), the obsidian was worked in the same manner as any other lithic resource-i.e., it was used to produce flake-based implements. By the later Neolithic different knapping traditions had emerged, for while Giali A raw material continued to be used to make flakes, Melian obsidian and chert were mainly employed for blade manufacture using skilled percussion and pressure techniques (Cherry and Torrence 1984; Carter 2009: 203). These distinctions are apparently due to Giali A obsidian's obvious knapping limitations: the abundance of spherulites makes it nearly impossible to control the removal of an elongated blank (blade) or hold a sharp cutting edge, as evidenced by the local FN population importing Melian obsidian for blade production while only working the local raw material in a much more ad hoc fashion (Sampson and Liritzis 1998: 104, fig. 13). While these materials had been used similarly during the Mesolithic, this differential use in the FN suggests that by this point the way these obsidians were conceptualized had begun to diverge. By the EBA, Giali A obsidian seems to have diminished in importance, and is attested at fewer sites than in the preceding two millennia (Figure 14.C). With so little of this material published, it is difficult to ascertain just what it was being used for at this time, although one suspects that in the Dodecanese, at least, it continued to serve as a supplementary raw material for opportunistic, minimally skilled tool-making.

While the casual use of readily available material and the long-distance transport of rare lithic materials are common characteristics of exploitation of lithic materials globally, the long-term consumption of Giali A obsidian does not conform well to any expected pattern. Given its poor quality as a tool-making material, why was any of it transported to Crete, the Cyclades, and western Anatolia during the Neolithic and EBA?

The distribution and consumption patterns of Giali A obsidian during these periods suggest that its transport was a consequence of long-distance trade, rather than a driver of it. The presence of Giali A obsidian at sites such as EN Knossos and LN Saliagos might be viewed as reflecting the maritime colonization routes taken by the migrant farmers from Anatolia who settled Crete and the Cyclades islands in the seventh and fifth millennium $\mathrm{Cal} \mathrm{BC}$ respectively, rather than evidence of significant socioeconomic ties with Dodecanesian populations (Evans 1994: 5; Broodbank 2000: 133-39; King et al. 2008). Similarly, population movement into the Dodecanese from the fifth millennium 
Cal BC likely explains the significant expansion in the number of communities using Giali $\mathrm{A}$ obsidian in the LN/FN (Figure 14.B), including the establishment of the first prehistoric settlement on Giali itself (Sampson 1988).

Similarly, the handfuls of Giali A obsidian in the LN-EBA Cyclades and Crete might be viewed as the by-product of contemporary maritime routes. For example, the few pieces of Giali A obsidian at the well-connected EBA site of Dhaskalio-Kavos on Keros (Broodbank 2000: 223-46) may have been collected by Cycladic voyagers as they paddled via the Dodecanese on the counter-clockwise return from Crete to the Cyclades (Figure 14.C), re-entering the archipelago through Amorgos (Agourides 1997: 11, fig. 5; Sherratt 2000: 18; for the later Neolithic see Papadatos and Tomkins 2013). Giali A obsidian on Keros might ultimately be viewed as emblematic of trade partnerships with inhabitants of the Dodecanese, relations that ultimately facilitated access to the emerging 'Anatolian Trade Network', a supra-regional web of socio-economic relations that linked western Anatolian factions with Mesopotamia (Şahoğlu 2005). Connections with this exchange system would have allowed the dominant characters of Cycladic society to gain access to a range of new practices and media through which social distinction could be maintained and expressed, not least tin, wheel-made pottery, and weapon types, inter alia (Broodbank 2000: 283-87; Sherratt 2000: 128).

Such arguments do reduce Giali A obsidian to something of an epiphenomenon, a mere reflection of socio-economic interaction, rather than useful and/or desirable media in its own right, but are consistent with the scale and character of the material's consumption. Ultimately, detailed contextual and functional analyses are needed to further resolve the issue of Giali A obsidian's importance as an exotic material during the Neolithic and EBA.

In contrast, by the earlier part of the second millennium Cal $\mathrm{BC}$ the evidence suggests that
Giali A obsidian was valued as symbolically laden exotica, worked by skilled palace-based lapidaries to make sealstones (insignia of highranking individuals) and vessels for elite and/or cultic use. At this point the raw material's procurement at a distance was apparently driven by a newly developed desire for this distinctive raw material in its own right, though its transport may still have accompanied metals being traded from central Anatolia via the Maeander River (Carter and Kilikoglou 2007: 134). Giali A obsidian's reconceptualization as a valued good can thus be viewed as part of the processes involved in the emergence of a state-level society on Crete at the start of the second millennium Cal вс. These political developments were partly achieved through intensified contacts with the major polities of Egypt, Anatolia, the Levant, and Mesopotamia beyond (Watrous 1987; 1998; Manning 1994: 244-46), a process that led certain Cretan factions to adopt foreign elite traditions, belief systems, and value regimes as novel modes of constituting social distinction on Crete. Stone vase and sealstone production are just two examples of such transformations in practice. These crafts had a long heritage on Crete, attested from the first half of the third millennium $\mathrm{BC}$, although initially the tradition primarily involved local and easy-to-work raw materials such as steatite (Warren 1969: 18285). The vessels served a range of functions that were clearly linked to modes of creating and expressing social distinction (Bevan 2007: 85-93), through feasting (serving and drinking vessels), body adornment (unguent containers), and funerary rites (as rich grave goods), while seals were employed to mark social identities, as protective devices, and for resource administration (Krzyszkowska 2005: 21-23). The supraregional relations developed in the early MBA facilitated the introduction by Cretan elites of a range of new elements to these practices, involving the adoption of new forms and the working of a wider range of raw materials (Krzyszkowska 2005: 81-82; Bevan 2007: 115-19). Some 
of these materials were foreign to Crete and significantly harder to work, and their appeal conceivably stemmed from the value associated with the skilled crafting necessary to work them and their distant origin (Helms 1993). By the Neopalatial period these exotic media included Anatolian (?) quartz crystal, Egyptian travertine, rosso antico and lapis lacedaemonius from the Greek mainland, and obsidian (Bevan 2007: 119-23), the latter almost exclusively the whitespotted Giali A (Warren 1969: 135-36).

The production of vases and other prestige items from Giali A obsidian by early MBA craftworkers in the Cretan palaces was a clear appropriation of contemporary Anatolian, Levantine, and Egyptian kingly/Pharaonic manufacturing traditions (Bevan 2007: 100-33). Obsidian drinking vessels, cosmetic containers, and boxes are viewed as 'standardized royal products' of Middle Kingdom Egypt (Figure 15); their findspots include the tombs of princesses at Lahun and Dahshur (Bevan 2007: 100-101, fig. 6.1). With some of these vessels circulating supra-regionally through elite gift exchange (as with an obsidian/gold jar and chest from Byblos inscribed by pharaohs Amenemhat III and IV [Kitchen 1967; Bevan 2007: 102-103, fig. 6.2]), and the Cretan elites' long-established taste for Egyptian or Egyptian-style stone-vases, we have a clear context for Cretan lapidaries becoming cognizant of obsidian's use for vessel manufacture (or the import of specialists from elsewhere), and their subsequent turn to the 'local' source of Giali to emulate this fashion.

Alternatively, and/or simultaneously, one could suggest that influences from central Anatolian palaces led to these developments on Crete. Obsidian vessels, one broken and mended with gold-wire, are documented from the twentieth- to nineteenth-century BC sites of Acemhöyük and Kültepe in Cappadocia (Figure 15 ), both centers of local royalty and so-called 'Assyrian trade colonies' (Özten 1988: pls. 3, 5, 14, 20a, 21b; Bevan 2007: 113-15, fig. 6.12). This is another world with which the Knossian and Maliote elites are known to have engaged, as attested by small quantities of Cappadocian raw materials, as well as imports and copies of Anatolian material culture and royal iconography (Carter and Kilikoglou 2007). An obsidian vessel workshop of this period is also known from Alalakh (Tel Atchana) in the northern Levant, where the products' forms drew on both Levantine and Egyptian traditions (Bevan 2007: 112-13; Sparks 2007: 179).

The appeal of obsidian in particular-previously a raw material associated with more mundane tool-making traditions-to Cretan elites may have been due to their adoption of Egyptian and Mesopotamian ideologies that associated obsidian and other reflective, iridescent, or brilliant media with divinity, leadership, and magico-religious protection (cf. Aufrère 2001: 160; Frahm 2010: 92-94; more generally, see Helms 1993: 150-52; Saunders 2001). Thus the symbolic power of the raw material was now appreciated, and drawn upon through new manufacturing traditions whose aims partly involved maximizing the obsidian's reflective surface (seals and vessels), rather than exploiting its fracture habit and cutting edge. From the later Bronze Age Eastern Mediterranean specifically, there are textual references to the medico-magical properties and cosmological significance of obsidian. For instance, in Pharaonic Egypt obsidian was associated with a group of stars, the sixteenth decan of the cycle of Sirius-Sothis; it was also the black of the eyes of Ra and Atoum (Decourt 1998: 355-56). In the Near East there are descriptions of necklaces that offered the wearer protection, mirrors for divination, and blades for ritual bloodletting (Coqueugniot 1998; Frahm 2010: 90-95). The link between brilliance and power/ divinity is particularly pertinent when considering the Vat Room Deposit assemblage from Protopalatial Knossos, where Giali A, Melian, and central Anatolian obsidians were found amidst an array of lustrous materials including rock crystal, gold, faience, and copper, a mix of cultic equipment and raw materials for making 
prestige goods (Panagiotaki 1998: 180, pl. 36a; 1999: 27, 62). Located in the palace's 'central palace sanctuary', such dual-purpose ritual/crafting spaces are known from broadly contemporary palatial complexes in Crete, Anatolia, Egypt, and Mesopotamia (Panagiotaki 1999: 41-42).

The white-spotted nature of Giali A obsidian may have further contributed to the material's significance through its invocation, or embodiment, of constellations (i.e., 'spherulites-asstars'). More specifically, it may have served as a 'local' version of the Egyptian high-status anorthosite gneiss, albeit in reverse form-black spots / white body - a color dualism that in Egyptian and Mesopotamian contexts would have provided such vessels with multi-layered cosmological associations, their use evoking such concepts as light and dark or good and evil (Bevan 2003: 68). Gneiss vases were being imitated in Crete from the end of the EBA using local travertine and dolomitic limestone (Bevan 2007: 96-97), while subsequently in Neopalatial Knossos we find identical vessel typescarinated bowls - made of Egyptian anorthosite gneiss and Giali A obsidian (Figure 4 [bottom]; see also Bevan 2003: 63, fig. 4.4c-d). Evans (1901-1902: 123, fig. 74) viewed the carinated bowl of Giali A obsidian as evidence for connections between Crete and Fourth Dynasty Egypt, which would make the piece a $1000+$ year old heirloom if an MM III find (Warren 1969: 75, P. 409; Bevan 2003: 63). It also represents a striking embodiment of foreign practices and value regimes being adopted by Cretan elites, and was arguably intended for use in a ceremonial pairing with the gneiss bowl.

Neopalatial Crete provides us with an array of Giali A obsidian vessels for drinking and libations, whose contexts of production and recovery, technical accomplishment, and stylistic elaboration clearly attest to their prestige status, likely handled by royalty and highranking religious officials alike (Figure 15.A). It is noteworthy that $70 \%$ of all known Giali A vessels come from Knossos, arguably the mytho- logical, if not political, center of Bronze Age Crete (Soles 1995), supra-regionally connected, and by extent the primary consumer of exotic goods and foreign practices (Bevan 2003). Skeuomorphism was a common element within the manufacturing traditions of these prestige goods, as with the shell rhyta from Aghia Triada and Palaikastro. In a related vein, this period (MM III) also witnessed the development of the 'white-spotted ware' ceramic tradition (Evans 1921: 417; MacGillivray 1998: 65), an even clearer emulation of Giali A obsidian than its 'white-flecked' Protopalatial antecedent; the angular form of some pots also suggests that they were also imitating metal vases (Figure 16). Here too the focus on cups, jugs, and an occasional rhyton, links the 'white-spotted' tradition to high-status drinking and/or libation rites (MacGillivray 1998: 64-65, pl. 17-18; Caloi 2013: 244, pl. XL, 840).

While Giali A obsidian is now attested (mainly visually) at a number of MBA/LBA Cretan sites (Figure 14.D), this is a socio-economically exclusive group of sites, including palaces and/or major urban complexes (Knossos, Malia, Aghia Triada, Palaikastro), cult centers (Mount Juktas), villas (Tylissos), and well-connected harbor communities (Mochlos, Poros-Katsambas, and Pseira [Betancourt 1997; Dimopoulou 1997: 434]). In most cases it is not finished vessels or sealstones that have been found, but handfuls of flakes, chips, and chunks. While this material could be debris from manufacturing elite and/ or cultic paraphernalia, such manufacture seems to have been a palace-controlled affair; as such, could these items instead be viewed as apotropaic trinkets in their own unmodified right? One might view the small quantities of Giali A obsidian in the EBA Cyclades in a similar nonutilitarian light (their appearance in the ritual 'Special Deposit South' on Keros is noteworthy); they may constitute small lustrous charms collected on the return voyage from Crete and Anatolia via the Dodecanese, and/or tokens of gift relations established between Cycladic 

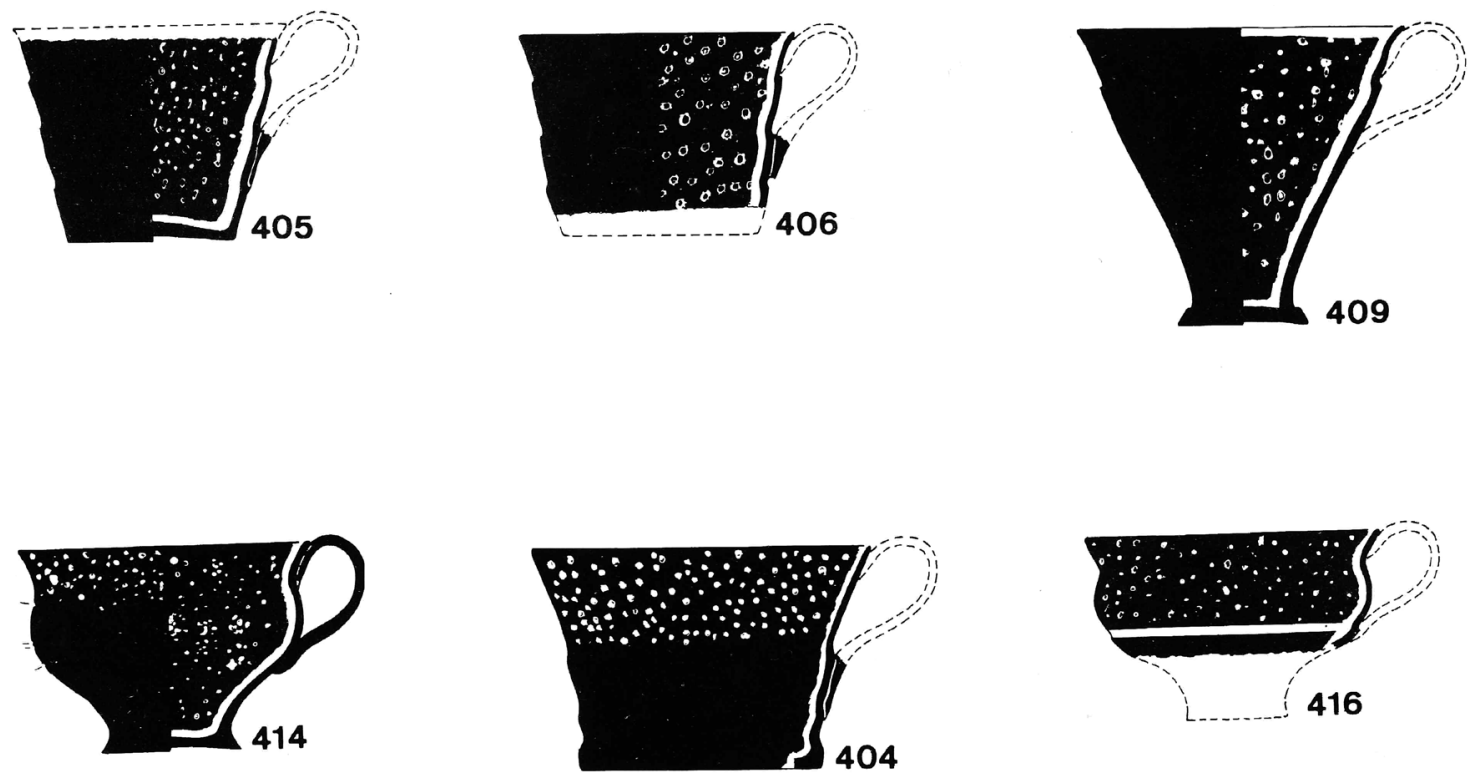

Figure 16. 'White-spotted style' ware; the tallest cup (409) is $10 \mathrm{~cm}$ high, with a rim diameter of $11 \mathrm{~cm}$. Adapted from MacGillivray 1998: pls. 17-18, with permission from the British School at Athens and J.A. MacGillivray.

residents and their Dodecanesian trade-partners or kin (cf. Sheppard 1993).

The distribution of Giali A obsidian artifacts during the MBA/LBA certainly also reflected networks of socio-economic relations (Figures 14.C-D). The circulation of finished vessels and sealstones may have been initiated by members of only a few palatial centers, perhaps gifted to their vassals or peers at home and abroad (e.g., the Vapheio royal tomb), while the communities in the Cyclades and Dodecanese where the obsidian is documented are known to have enjoyed close links to Cretan factions (e.g., Davis et al. 1983). The Neopalatial period on Crete represents both the apogee and final period of use of Giali A obsidian; none is securely dated to the subsequent 'Final Palace' period. During this latter part of the Bronze Age, which followed the destruction of most major sites, Crete came under influence-if not colonized control—of the mainland Mycenaean culture, a process that led to the reconfiguration of elite practices and value systems. Stone vessels were produced in lesser numbers and with a restricted repertoire, with a greater emphasis on importing Egyptian goods rather than local manufacture of highquality products (Bevan 2007: 157-65).

\section{Conclusion}

The patterns in exploitation of Giali A obsidian through time demonstrate some of the ways in which patterns of interaction in the Aegean shifted during the ninth to second millennium Cal BC, and suggest that modes of consumption can significantly influence the circulation of raw materials. The distribution of Giali A obsidian (Figure 14) shifted in ways that reflected larger changes in regional interconnection, a process driven by both political agents and transportation advances. These changes opened up new cosmological and ideological vistas as well as socio-economic and socio-political opportunities, which combined to change the value ascribed to this raw material and the ways in which it was used. 
Interpreting these evolving patterns requires not only source studies and raw material sourcing, but also an analysis of consumption patterns. The characterization of Giali obsidian that we have presented here builds on earlier work to produce what is now a fairly standard narrative of obsidian sourcing: characterization of source material, matching of artifactual material to the distinct source profile, and an overview of the raw material's distributions in space and time. We argue that this approach can and should be developed further: in order to interpret the material's distribution, one needs to include a consideration of the ways in which the raw material was used.

The diachronic distribution patterns of Giali A obsidian are notably distinct from those of Melian obsidian (Carter 2009; Milić 2014). Giali A obsidian was employed locally during the Mesolithic to EBA for tool production, while by the MBA it had become a raw material transported long distances for the manufacture of luxury goods by and/or for Cretan elites. This shift was apparently driven by a conceptual transformation, as Giali A obsidian, once considered a poor-quality raw material for making stone tools, became a raw material valued for the skilled and exclusive manufacture of groundstone vessels and sealstones.

The fact that Giali A obsidian was reconceptualized in this manner, rather than simply falling out of use entirely as better-quality lithic resources and metals became more accessible, provides compelling evidence of the role of shifting value regimes in the exploitation and diffusion of raw materials in the second-millennium $\mathrm{Cal} \mathrm{BC}$ Aegean. This demonstrable change in the worth of Giali A obsidian, coupled with the persistent neglect by Cretan palatial vase and sealstone makers of obsidian from the closer Melos sources (available, if less abundant, in blocks of sufficient size), argues that some particular value was ascribed to Giali A obsidian per se. This shift in the obsidian's worth may have been related to its aesthetic/cosmological properties (i.e., the whitespots-on-black-background that were copied in ceramic form), or a reluctance to use quotidian media such as Melian obsidian for prestige/ritual goods-although in MBA/LBA central Anatolia one does see the simultaneous use of Göllü Dağ obsidian for both domestic tools and elite items (Carter and Kilikoglou 2007: 131). One might also consider the greater distances from Crete involved in procuring obsidian from the Dodecanese (a gateway to foreign practices and value regimes), or some combination of these and other as-yet unknown factors. Had Giali A obsidian been of interest only for its potential use as a material for knapping, surely its value would have simply declined over time.

This perspective suggests at least some of the reasons why Aegean obsidians continued to be used for so long after the introduction of metallurgy, in contrast to the trajectories of use of the central and western Mediterranean obsidians. In the Aegean, Melian and Giali A obsidians were exploited up until the end of the Bronze Age (late second millennium Cal $\mathrm{BC}$ ) because of particular functional desires that derived from and/ or aligned with wider eastern Mediterranean traditions and value regimes. These comprised an emphasis on male depilation (and thus the manufacture of Melian obsidian razors, as facial hair was the preserve of society's upper echelons [Carter 1997: 545-46]), and the manufacture of Giali A obsidian vessels and jewelry for elite/ cultic consumption. In contrast, the dwindling desire for obsidian in the post-Neolithic central and western Mediterranean reflects the emergence of new strategies for social distinction within Central and Western Europe. That region, previously comprising a world that had valorized participation in exchange networksas partly articulated through the circulation of obsidian-became one where social distinction was achieved through inter-personal violence using new metal weapons and new forms of ceremonial drinking in 'beakers' (Freund 2014a). 
While the case of Giali A obsidian is unique in some respects - the material is not only distinctive, but also ill-suited to manufacture of flaked stone tools - this demonstrable evolution of value nevertheless offers a broadly applicable lesson: distribution patterns and value regimes can best be interpreted through integrated characterization and consumption studies.

\section{Appendix: Online Supplementary Data}

1. EDXRF analytical procedures.

2. Discriminant function analysis results.

These are both available at http://dx.doi. org/10.1558/jmea.v29i1.31014

\section{Acknowledgments}

Permission for geological research on Giali came from the Institute of Greek Mining and Exploration (Irene Zananiri and Alexandra Zervakou), while Dimitris Chanis of the Lava Mining and Quarrying Company facilitated transport to the island in 2012. The research was funded by the Social Sciences and Humanities Research Council, while the MAX Lab was established by a Canada Foundation for Innovation Leader's Opportunity Fund / Ontario Research Fund. François-Xavier Le Bourdonnec prepared the cut samples, while Kelly Brown and Sarah Grant ran many of the EDXRF analyses. Thanks to Yiannis Bassiakos, Illaria Caloi, John Cherry, James Conolly, Maud Devolder, Don Evely, Mercourios Georgiadis, Stella Katsarou, Neyir Kolankaya-Bostancı, Sandy MacGillivray, Colin Macdonald, Toula Marketou, Vagia Mastrogiannopoulou, and Marina Milić for help in preparing this paper, and to the Herakleion Archaeological Museum (Eleni A. Tziraki) and the British School at Athens (Amalia Kakissis) for permission to reproduce images. Comments from Robin Torrence, three anonymous reviewers, and the JMA editors helped significantly sharpen the paper.

\section{About the Authors}

Tristan Carter employs multi-faceted stone tool studies to engage with major debates in eastern Mediterranean prehistory spanning the Lower Palaeolithic to Late Bronze Age. Working primarily in Greece (Malia, Mochlos), and Turkey (Çatalhöyük, and Göbekli Tepe), he has directed the MAX Lab since 2009, and the Stélida Naxos Archaeological Project since 2013.

Daniel Contreras is a Labex OT-Med postdoctoral research fellow for the AMENOPHYS Project at Aix-Marseille Université. His research focuses on human-environment interactions in the past, particularly the linked trajectories of anthropogenic and environmental change and ways of examining diverse human modifications of landscapes. His active field projects include research at Chavín de Huántar and in Ayacucho in Peru, in the Wadi al-Hasa, Jordan, and Stélida on Naxos, and he has worked at obsidian sources in Peru, Greece, and Turkey.

Kathryn Campeau is an Honors Anthropology student at McMaster University. Since 2013 she has been a Research Assistant in the MAX Lab, and a team member of the Stélida Naxos Archaeological Project.

Kyle Freund's primary research centers on prehistoric farming communities of the central Mediterranean, with an emphasis on the reflexive relationship between material culture and long-term social processes. His specializations include archaeometallurgy, lithic analysis, spatial statistics, and field survey.

\section{References}

Acquafredda, P., and A. Paglionico

2004 SEM-EDS microanalysis of microphenocrysts of Mediterranean obsidians: a preliminary approach to source discrimination. European Journal of Mineralogy 16: 419-29. http://dx.doi. org/10.1127/0935-1221/2004/0016-0419

Agourides, C.

1997 Sea routes and navigation in the third millennium 
Aegean. Oxford Journal of Archaeology 16: 1-24. http://dx.doi.org/10.1111/1468-0092.00022

Arias, A., M. Oddone, G. Bigazzi, A. Di Muro, C. Principe and P. Norelli

2006 New data for the characterization of Milos obsidians. Journal of Radioanalytical and Nuclear Chemistry 268: 371-86. http://dx.doi.org/ 10.1007/s10967-006-0183-9

Aufrère, $S$.

2001 The Egyptian temple, substitute for the mineral universe. In W.V. Davies (ed.), Colour and Painting in Ancient Egypt, 158-63. London: British Museum Press.

Bassiakos, Y., V. Kilikoglou and A. Sampson

2005 Yali island: geological and analytical evidence for a new source of workable obsidian. International Association of Obsidian Studies Bulletin 33: 18.

Bellot-Gurlet, L., O. Pelon and M.L. Séfériadès

2008 Détermination de provenance d'une sélection d'obsidiennes du palais minoen de Malia (Crète). Comptes Rendus Palevol 7: 419-27. http://dx.doi.org/10.1016/j.crpv.2008.07.005

Betancourt, P.P.

1997 The trade route for Ghyali obsidian. In R. Laffineur and P.P. Betancourt (eds.), TECHNE: Craftsmen, Craftswomen and Craftsmanship in the Aegean Bronze Age. Aegaeum 16: 171-75. Liège, Belgium and Austin: Université de Liège, University of Texas at Austin.

Bevan, A.

2003 Reconstructing the role of Egyptian culture in the value regimes of the Bronze Age Aegean: stone vessels and their social contexts. In $\mathrm{R}$. Matthews and C. Roemer (eds.), Ancient Perspectives on Egypt, 57-73. London: UCL Press.

2007 Stone Vessels and Values in the Bronze Age Mediterranean. Cambridge: Cambridge University Press. http://dx.doi.org/10.1017/ CBO9780511499678

Bigazzi, G., and G. Radi

1981 Datazione con le tracce di fissione per l'identificazione della provenienza dei manufatti di ossidiana. Rivista di Scienze Preistoriche Firenze 36: 223-50.

Broodbank, C.

2000 An Island Archaeology of the Early Cyclades. Cambridge: Cambridge University Press.

Buchholz, H.-G., and E. Althaus
1982 Nisyros, Giali, Kos: Ein Vorbericht über archäologisch-mineralogische Forschungen auf Griechischen Inseln. Mainz: Philipp von Zabern.

Caloi, I.

2013 Festòs protopalaziale: Il quartiere ad ovest del Piazzale I. Strutture e ritrovamenti delle terrazze mediana e superiore. Venezia: Edizioni Ca’ Foscari.

Cann, J.R., J.E. Dixon and C. Renfrew

1968 Appendix IV: the sources of the Saliagos obsidian. In J.D. Evans and C. Renfrew (eds.), Excavations at Saliagos near Antiparos. British School at Athens Supplementary Volume 5: 105-107. London: British School at Athens.

Carter, $\mathrm{T}$.

1997 Blood and tears: a Cycladic case study in microwear analysis. The use of obsidian blades as razors? In M.A. Bustillo and A. Ramos-Millán (eds.), Siliceous Rocks and Culture, 256-71. Madrid: Consejo Superior de Investigaciones Científicas.

2009 L’obsidienne égéenne: caractérisation, utilisation et culture. In M.-H. Moncel and F. Fröhlich (eds.), L'Homme et le précieux: matières minérales précieuses de la préhistoire à aujourd'hui. British Archaeological Reports, International Series S1934: 199-212. Oxford: Archaeopress.

Carter, T., and D. Contreras

2012 The character and use of the Soros Hill obsidian source, Antiparos (Greece). Comptes Rendus Palevol 11: 595-602. http://dx.doi. org/10.1016/j.crpv.2012.06.005

Carter, T., S. Grant, M. Kartal, A. Coşkun and V. Özkaya 2013 Networks and Neolithisation: sourcing obsidian from Körtik Tepe (SE Anatolia). Journal of Archaeological Science 40: 556-69. http://dx.doi. org/10.1016/j.jas.2012.08.003

Carter, T., and V. Kilikoglou

2007 From reactor to royalty? Aegean and Anatolian obsidians from Quartier Mu, Malia (Crete). Journal of Mediterranean Archaeology 20: 11543. http://dx.doi.org/10.1558/jmea.v20i1.115

Carter, T., and M. Milić

2013 The chipped stone industry from Dhaskalio. In C. Renfrew, O. Philaniotou, N. Brodie, G. Gavalas and M.J. Boyd (eds.), The Settlement at Dhaskalio: The Sanctuary at Keros and the Origins of Aegean Ritual I, 531-56. Cambridge: McDonald Institute for Archaeology. 
Chapouthier, F., and P. Demargne

1942 Fouilles exécutées à Mallia. Troisième rapport: Exploration du Palais (1927-1932). Études Crétoises VI. Paris: Libraire Orientaliste Paul Geuthner.

Cherry, J.F

1981 Pattern and process in the earliest colonisation of the Mediterranean islands. Proceedings of the Prehistoric Society 47: 41-68. http://dx.doi. org/10.1017/S0079497X00008859

Cherry, J.F., and R. Torrence

1984 The typology and chronology of chipped stone assemblages in the prehistoric Cyclades. In J.A. MacGillivray and R.L.N. Barber (eds.), The Prehistoric Cyclades: Contributions to a Workshop on Cycladic Chronology, 12-25. Edinburgh: Department of Classical Archaeology.

Cherry, J.F., R. Torrence and S.E. Warren

n.d. Archaeological Survey and Characterisation of the Obsidian Source on Giali in the Dodecanese, Greece. Athens: Unpublished document housed in the library of the British School at Athens.

Coleman, J.E.

1977 Kephala: A Late Neolithic Settlement and Cemetery. Keos I. Princeton, New Jersey: Princeton University Press.

Costa, L.J.

2007 L'Obsidienne: un témoin d'échanges en Méditerranée préhistorique. Paris: Éditions Errance.

Coqueugniot, É.

1998 L'obsidienne en Méditerranée orientale aux époques post-Néolithiques. In M.-C. Cauvin, A. Gourgaud, B. Gratuze, N. Arnaud, G. Poupeau, J.-L., Poidevin and C. Chataigner (eds.), L'Obsidienne au proche et moyen Orient: $d u$ volcan à l'outil. British Archaeological Reports, International Series 738: 379-82. Oxford: Archaeopress.

D’Annibale, C.

2008 Obsidian in transition: the technological reorganisation of the obsidian industry from Kephala Petras (Siteia) between Final Neolithic IV and Early Minoan I. In V. Isaakidou and P.D. Tomkins (eds.), Escaping the Labyrinth: The Cretan Neolithic in Context, 191-200. Oxford: Oxbow Books.

Davis, J.L., E. Schofield, R. Torrence and D.F. Williams

1983 Keos and the eastern Aegean: the Cretan connection. Hesperia 52: 361-66. http://dx.doi. org/10.2307/147970
Decourt, J.-C.

1998 L'obsidienne dans les sources anciennes: notes sur l'histoire du mot et l'utilisation de la roche dans l'antiquité. In M.-C. Cauvin, A. Gourgaud, B. Gratuze, N. Arnaud, G. Poupeau, J.-L., Poidevin and C. Chataigner (eds.), L'Obsidienne au proche et moyen Orient: du volcan à l'outil. British Archaeological Reports, International Series 738: 363-77. Oxford: Archaeopress.

Dimopoulou, N.

1997 Workshops and craftsmen in the harbour-town of Knossos at Poros-Katsambas. In R. Laffineur and P.P. Betancourt (eds.), TECHNE: Craftsmen, Craftswomen and Craftsmanship in the Aegean Bronze Age. Aegaeum 16: 433-38. Liège, Belgium and Austin: Université de Liège, University of Texas at Austin.

Evans, A.J.

1901-02 The Palace of Knossos: provisional report of the excavations for the year 1902. Annual of the British School at Athens 8: 1-124. http://dx.doi. org/10.1017/S0068245400001404

1902-03 The Palace of Knossos: provisional report for the year 1903. Annual of the British School at Athens 9: 1-153. http://dx.doi.org/10.1017/ S0068245400007656

1921 The Palace of Minos at Knossos I. The Neolithic and Early and Middle Minoan Ages. London: Macmillan.

Evans, J.D.

1994 The early millennia: continuity and change in a farming settlement. In R.D.G. Evely, H. Hughes-Brock and N. Momigliano (eds.), Knossos, A Labyrinth of History: Papers Presented in Honour of Sinclair Hood, 1-20. London: British School at Athens, London.

Farr, H.

2006 Seafaring as social action. Journal of Maritime Archaeology 1: 85-99. http://dx.doi. org/10.1007/s11457-005-9002-7

Frahm, E.E.

2010 The Bronze-Age Obsidian Industry at Tell Mozan (Ancient Urkesh), Syria: Redeveloping Electron Microprobe Analysis for 21st-Century Sourcing Research and the Implications for Obsidian Use and Exchange in Northern Mesopotamia after the Neolithic. Unpublished PhD dissertation, Department of Anthropology, University of Minnesota, Minneapolis. 
Freund, K.

2014a A Multi-Scalar Analysis of the Politics of Obsidian Consumption in the West Mediterranean (ca. 6th - 2nd millennia B.C.). Unpublished PhD thesis, Department of Anthropology, McMaster University, Hamilton, Ontario.

2014b Obsidian consumption in Chalcolithic Sardinia: a view from Bingia 'e Monti. Journal of Archaeological Science 41: 242-50. http://dx.doi. org/10.1016/j.jas.2013.08.016

Galanidou, N.

2002 The chipped stone industry of Ftelia: an introduction. In A. Sampson (ed.), The Neolithic Settlement at Ftelia, Mykonos, 317-32. Rhodes, Greece: University of the Aegean.

Georgiadis, M.

2008 The obsidian in the Aegean beyond Melos: an outlook from Yali. Oxford Journal of Archaeology 27: 101-11. http://dx.doi.org/10.1111/j.14680092.2008.00299.x

2011 Kos in the Neolithic and Early Bronze Age: The Halasarna Finds and the Aegean Settlement Pattern. Philadelphia: INSTAP Academic Press.

Hankey, V.

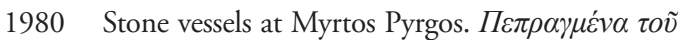

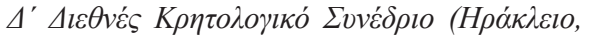

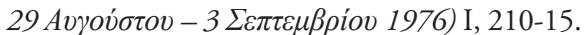
Helms, M.W.

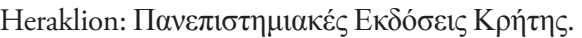

1993 Craft and the Kingly Ideal: Art, Trade and Power. Austin: University of Texas Press.

Hughes, H.M.C., and P. Warren

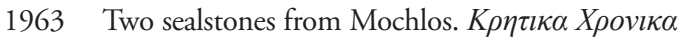
17: 352-56.

Innocenti, F., N. Kolios, P. Manetti, F. Rita and L. Villari 1982 Acid and basic Late Neogene volcanism in Central Aegean Sea: its nature and geotectonic significance. Bulletin of Volcanology 45: 87-97. http://dx.doi.org/10.1007/BF02600426

Kaczanowksa, M., and J.K. Kozlowski

2014 The Aegean Mesolithic: material culture, chronology and networks of contact. Eurasian Prehistory 11(1): 31-61.

Katsarou, S., A. Sampson and E. Dimou

2002 Obsidian as temper in Yali Neolithic pottery, Greece. In V. Kilikoglou, A. Hein and Y. Maniatis (eds.), Modern Trends in Scientific Studies on Ancient Ceramics. British Archaeological Reports, International Series 1011: 111-20. Oxford: Archaeopress.
King, R., S. Özcan, T. Carter, E. Kalfoglu, S. Atasoy, K. Triantiphyllidis, A. Kouvatsi, A. Lin, C. Chow, L. Zhivotovsky, M. Tsopanomichalou and P. Underhill

2008 Differential Y-chromosome Anatolian influences on the Greek and Cretan Neolithic. Annals of Human Genetics 72: 205-14. http://dx.doi.org/ 10.1111/j.1469-1809.2007.00414.x

Kitchen, K.A.

1967 Byblos, Egypt, and Mari in the early second millennium Bс. Orientalia 36: 39-54.

Krzyszkowska, O.

2005 Aegean Seals: An Introduction. Bulletin of the Institute of Classical Studies Supplement 85. London: Institute of Classical Studies.

Lykousis, V.

2009 Sea-level changes and shelf break prograding sequences during the last $400 \mathrm{ka}$ in the Aegean margins: subsidence rates and palaeogeographic implications. Continental ShelfResearch 29: 2037 44. http://dx.doi.org/10.1016/j.csr.2008.11.005

Macdonald, C.F., and C. Knappett

2007 Knossos: Protopalatial Deposits in Early Magazine $A$, and the South-West Houses. British School at Athens Supplementary Volume 41. London: British School at Athens.

MacGillivray, J.A.

1998 Knossos: Pottery Groups of the Old Palace Period. British School at Athens Studies 5. London: British School at Athens.

Mackenzie, D.

1904 The successive settlements at Phylakopi in their Aegeo-Cretan relations. In T.D. Atkinson, R.C. Bosanquet, C.C. Edgar, A.J. Evans, D.G. Hogarth, D. Mackenzie, C. Smith and F.B. Welch (eds.), Excavations at Phylakopi in Melos. Society for the Promotion of Hellenic Studies Supplementary Volume 4: 238-72. London: Macmillan.

Manning, S.W.

1994 The emergence of divergence: development and decline on Bronze Age Crete and the Cyclades. In C. Mathers and S. Stoddart (eds.), Development and Decline in the Mediterranean Bronze Age. Sheffield Archaeological Monographs 8: 221-70. Sheffield: Sheffield Academic Press.

Marketou, T.

2009 Ialysos and its neighbouring areas in the MBA and LB I periods: a chance for peace. In C.F. Macdonald, E. Hallager and W.-D. Niemeier (eds.), The Minoans in the Central, Eastern, and 
Northern Aegean - New Evidence I. Monographs of the Danish Institute at Athens 8: 73-96. Athens: Danish Institute at Athens.

McDougall, J.M., D.H. Tarling and S.E. Warren

1983 The magnetic sourcing of obsidian samples from Mediterranean and Near Eastern sources. Journal of Archaeological Science 10: 441-52. http:// dx.doi.org/10.1016/0305-4403(83)90059-6

Milić, M.

2014 PXRF characterisation of obsidian from central Anatolia, the Aegean and central Europe. Journal of Archaeological Science 41: 285-96. http:// dx.doi.org/10.1016/j.jas.2013.08.002

Moundrea-Agrafioti, H.A.

1990 Akrotiri, the chipped stone: reduction technique and tools of the LC I phase. In D.A. Hardy, C. Doumas and J. Sakellarakis (eds.), Thera and the Aegean World III, 1, 390-406. London: Thera Foundation.

Nowicki, K.

2014 Final Neolithic Crete and the Southeast Aegean. Berlin: Walter de Gruyter. http://dx.doi.org/ $10.1515 / 9781614510376$

Özten, A.

1988 Acemhöyük taş kapları. Belleten 52: 393-406.

Panagiotaki, M.

1998 The Vat Room deposit at Knossos: the unpublished notes of Sir Arthur Evans. Annual of the British School at Athens 93: 167-84. http:// dx.doi.org/10.1017/S0068245400003415

1999 The Central Palace Sanctuary at Knossos. British School at Athens Supplementary Volume 31. London: British School at Athens.

Papadatos, Y., and P. Tomkins

2013 Trading, the longboat, and cultural interaction in the Aegean during the late fourth millennium B.C.E.: the view from Kephala Petras, East Crete. American Journal of Archaeology 117: 353-81. http://dx.doi.org/10.3764/

Pecorella, P.E. aja.117.3.0353

1984 La Cultura Preistorica di Iasos in Caria. Rome: Bretschneider.

Pelon, O.

1982 L'épée à l'acrobate et la chronologie maliote. Bulletin de correspondance hellénique 106(1): 165-90.

Perissoratis, C., and N. Conispoliatis

2003 The impacts of sea-level changes during latest
Pleistocene and Holocene times on the morphology of the Ionian and Aegean seas (SE Alpine Europe). Marine Geology 196: 145-56.

Platon, N., I. Pini and G.H. Salies (eds.)

1977 Corpus der Minoischen und Mykenischen Siegel II, 2. Die Siegel der Altpalastzeit. Iraklon, Archäologisches Museum 2. Berlin: Mann Verlag.

Pollard, M.A., and C. Heron

2008 Archaeological Chemistry. Cambridge: RSC Publishing.

Renfrew, C., J.R. Cann and J.E. Dixon

1965 Obsidian in the Aegean. Annual of the British School at Athens 60: 225-47.

Runnels, C.

2014 Early Palaeolithic in the Greek islands? Journal of Mediterranean Archaeology 27: 211-30.

Şahoğlu, V.

2005 The Anatolian trade network and the Izmir region during the Early Bronze Age. Oxford Journal of Archaeology 24: 339-61.

Sampson, A.

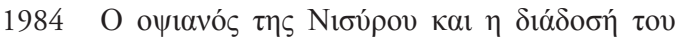

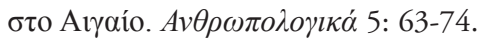

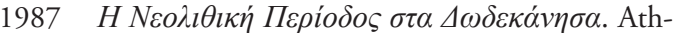
ens: Ekdosi tou Tameiou Archaiologikon Poron kai Apallotrioseon.

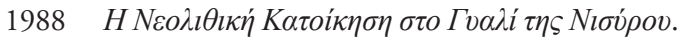
Athens: Evoiki Arheofilos Eteria.

Sampson, A., M. Kaczanowska and J.K. Kozlowski

2012 Mesolithic occupations and environments on the island of Ikaria, Aegean, Greece. Folia Quaternaria 80: 5-40.

Sampson, A., and I. Liritzis

1998 Archaeological and archaeometrical research at Yali, Nissiros. TÜBA-AR 2: 101-15.

Saunders, N.

2001 A dark light: reflections on obsidian in Mesoamerica. World Archaeology 33: 220-36.

Shelford, P., F. Hodson, M.E. Cosgrove, S.E. Warren and C. Renfrew

1982 The sources and characterisation of Melian obsidian. In C. Renfrew and M. Wagstaff (eds.), An Island Polity: The Archaeology of Exploitation on Melos, 182-91. Cambridge: Cambridge University Press.

Sheppard, P.J.

1993 Lapita lithics: trade/exchange and technology. Archaeology in Oceania 28: 121-37. 
Sherratt, S.

2000 Catalogue of Cycladic Antiquities in the Ashmolean Museum. The Captive Spirit I. Text. Oxford: Oxford University Press.

Soles, J.S.

1995 The functions of a cosmological center: Knossos in Palatial Crete. In R. Laffineur and W.-D. Niemeier (eds.), POLITEIA: Society and State in the Aegean Bronze Age. Aegaeum 12: 405-14. Liège, Belgium and Austin: Université de Liège, University of Texas at Austin.

Sparks, R.T.

2007 Stone Vessels in the Levant. Palestine Exploration Fund Annual 8. Leeds: Maney Publishing.

Stewart, S.J., G. Cernicchiaro, R.B. Scorzelli, G. Poupeau, P. Acquafredda and A. De Francesco

2003 Magnetic properties and ${ }^{57} \mathrm{Fe}$ Mössbauer spectroscopy of Mediterranean prehistoric obsidians for provenance studies. Journal of Non-Crystalline Solids 323: 188-92.

Tomkins, P.D.

2008 Time, space and the reinvention of the Cretan Neolithic. In V. Isaakidou and P.D. Tomkins (eds.), Escaping the Labyrinth: The Cretan Neolithic in Context, 21-48. Oxford: Oxbow Books.
Vaughan, S.J.

1990 Petrographic analysis of the Early Cycladic wares from Akrotiri, Thera. In D.A. Hardy, C. Doumas and J. Sakellarakis (eds.), Thera and the Aegean World III, 1, 470-87. London: Thera Foundation.

Warren, P.

1969 Minoan Stone Vases. Cambridge: Cambridge University Press.

Watrous, L.V.

1987 The role of the Near East in the rise of the Cretan palaces. In R. Hägg and N. Marinatos (eds.), The Function of the Minoan Palaces. Skrifter Utgivna av Svenska Institutet i Athen 35: 65-70. Stockholm: Swedish Institute at Athens.

1998 Egypt and Crete in the Early Middle Bronze Age: a case of trade and cultural diffusion. In E.H. Cline and D. Harris-Cline (eds.), The Aegean and the Orient in the Second Millennium. Aegaeum 18: 19-28. Liège, Belgium and Austin: Université de Liège, University of Texas at Austin.

Xenaki-Sakellariou, A.

1964 Die minoischen und mykenischen Siegel des Nationalmuseums in Athen 1. Berlin: Mann. 